\title{
Contemporary infectious exanthems: an update
}

\author{
Francesco Drago', Giulia Ciccarese ${ }^{* 1}$, Giulia Gasparini', Ludovica Cogorno', \\ Sanja Javor ${ }^{1}$, Antonio Toniolo ${ }^{2} \&$ Francesco Broccolo ${ }^{3}$
}

An exanthem is a skin rash that may be associated with mucous membrane eruption, fever or other symptoms. It may develop as manifestation of an infectious disease or as adverse reaction to drugs. Beside the 'classical exanthems' commonly occurring in childhood, other exanthems, defined as 'atypical' for the different morphology and causal agents, may occur. Among the atypical exanthems with infectious etiology, viral, bacterial, parasitic and helminth infections are implicated. We describe herein etiology and epidemiology of the atypical exanthems caused by infectious agents. In case of exanthem, to make a correct etiological diagnosis is crucial for both the patient and community concerning issues such as time off school, immunizations and risk in pregnancy and immunocompromised individuals.

First draft submitted: 21 July 2016; Accepted for publication: 24 October 2016; Published online: 14 November 2016

An exanthem is defined as any eruptive skin rash that may be associated with lesions of the mucous membranes (enanthem), fever or systemic symptoms. It may be the manifestation of an infectious disease or an adverse reaction to drugs and is among the most frequent reasons for consultation of a dermatologist [1]. Beside the 'classic exanthems' (Table 1) [2], other exanthems with different morphology and caused by different infectious/toxic agents may occur. These skin rashes have been defined as 'atypical exanthems' $[1,3]$. Other authors [4,5] distinguished the so-called 'paraviral exanthems' as the skin diseases suspected to be caused by viruses, but with a single virus-exanthem relationship not universally accepted. However, we prefer the term 'atypical' for defining the exanthems that are different from the classic ones, because there are many skin rashes, like the sixth disease, that may have more than a single well-demonstrated virus as causal agent. Therefore, accepting the definition 'paraviral,' the exanthem list should become too much long.

Etiological diagnosis of atypical exanthems is difficult but important for both the patient and community concerning issues such as time off school, immunizations and risk for pregnant women and immunocompromised patients. Among the infectious exanthems, viral, bacterial, parasitic and helminths infections are implicated. Distinguishing viral exanthems from other life-threatening bacterial and rickettsial diseases with similar cutaneous manifestations may be crucial. Although the pathogenesis is little known, skin manifestation can result by the direct inoculation of the infectious agent into the cutaneous surface or by dissemination from a distant site. Alternatively, it may result from an immune response between the virus and antibody or cell-mediated response to virus in the skin (Table 2) [6].
'DISSAL Department of Dermatology, IRCCS AOU San Martino-IST, Largo Rosanna Benzi, 10, 16132 Genoa, Italy ${ }^{2}$ Laboratory of Medical Microbiology, Department of Biotechnology \& Life Sciences, University of Insubria, Varese, Italy ${ }^{3}$ Laboratory of Molecular Microbiology \& Virology, School of Medicine, University of Milano-Bicocca, 20900 Monza, Italy *Author for correspondence: Tel.: +39 010555 5750; Fax +39 010555 6509; giuliaciccarese@libero.it

\section{KEYWORDS}

- bacteria $\bullet$ diagnosis

- exanthem $\bullet$ parasite $\bullet$ skin eruption $\bullet$ skin infection

- skin rash • virus 


\begin{tabular}{|c|c|c|c|c|}
\hline Disease & $\begin{array}{l}\text { Infectious } \\
\text { agent }\end{array}$ & $\begin{array}{l}\text { Average } \\
\text { incubation } \\
\text { time }\end{array}$ & Appearance and distribution of rash & Other features \\
\hline Measles & $\begin{array}{l}\text { Measles virus } \\
\text { (paramyxovirus) }\end{array}$ & 14 days & $\begin{array}{l}\text { Red, raised papules (sometimes } \\
\text { confluent) on the face and neck } \\
\text { spreading to trunk and limbs }\end{array}$ & $\begin{array}{l}\text { Prodromes with fever, cough and coryza; } \\
\text { fever rises when rash appears; koplik's } \\
\text { spot: white lesions on a red granular } \\
\text { appearance mucosal surface }\end{array}$ \\
\hline Atypical measles & $\begin{array}{l}\text { Measles virus } \\
\text { (paramyxovirus) }\end{array}$ & 14 days & $\begin{array}{l}\text { Urticarial/maculopapular/heamorragic } \\
\text { lesions on the face and neck spreading to } \\
\text { trunk and upper extremities, sparing the } \\
\text { lower extremities }\end{array}$ & $\begin{array}{l}\text { Modified type of measles that occurs with } \\
\text { mild symptoms in adolescents/adults who } \\
\text { have been immunized previously with } \\
\text { killed measles vaccine and subsequently } \\
\text { exposed to wild-type measles }\end{array}$ \\
\hline Rubella & Rubella virus & 17 days & $\begin{array}{l}\text { Pink macules and papules on the whole } \\
\text { body surface }\end{array}$ & $\begin{array}{l}\text { Suboccipital lymphadenopathy; few or no } \\
\text { constitutional symptoms in children }\end{array}$ \\
\hline Varicella (chickenpox) & $\begin{array}{l}\text { Varicella zoster } \\
\text { virus }\end{array}$ & 16 days & $\begin{array}{l}\text { Successive crops of lesions that are } \\
\text { simultaneously present in various stages } \\
\text { of morphogenesis (macules, papules, } \\
\text { vesicles and crusts). The exanthem begins } \\
\text { on the trunk spreading on the neck, face } \\
\text { and limbs }\end{array}$ & Prodromes with malaise and fever \\
\hline $\begin{array}{l}\text { Scarlet fever } \\
\text { (streptococcal } \\
\text { disease) }\end{array}$ & $\begin{array}{l}\text { Streptococcus } \\
\beta \text { emoliticus } \\
\text { (group A) and } \\
\text { its exotoxins }\end{array}$ & $1-5$ days & $\begin{array}{l}\text { Scarlet papules on the whole body } \\
\text { surface except inside of elbows and } \\
\text { around mouth; hyperpigmentation in } \\
\text { skin creases }\end{array}$ & $\begin{array}{l}\text { Chills, fever, sore throat; strawberry tongue; } \\
\text { desquamation after rash }\end{array}$ \\
\hline $\begin{array}{l}\text { Fifth disease } \\
\text { (erythema } \\
\text { infectiosum) }\end{array}$ & Parvovirus B 19 & 7 days & $\begin{array}{l}\text { Slapped cheek appearance; } \\
\text { maculopapular rash with a typical } \\
\text { reticular pattern }\end{array}$ & Mild fever, headache, chills, malaise \\
\hline $\begin{array}{l}\text { Roseola infantum } \\
\text { (exanthema subitum, } \\
\text { sixth disease) }\end{array}$ & $\begin{array}{l}\text { Human herpes } \\
\text { virus } 6 B \text { or } 7\end{array}$ & 9 days & $\begin{array}{l}\text { Pink/erythematous macules and papules } \\
\text { primarily on the neck and trunk }\end{array}$ & $\begin{array}{l}\text { High fever and lymphadenopathy: fever } \\
\text { drops as rash appears (opposite of measles) }\end{array}$ \\
\hline
\end{tabular}

As classic exanthems are well known to clinicians, we summarized their main features (Table 1) [2] and describe etiology and epidemiology of the atypical exanthems caused by viral, bacterial, parasitic and helminthic infections.

\section{Viral exanthems \\ - Eczema herpeticum or Kaposi's varicelliform eruption}

Eczema herpeticum is a rare, potentially fatal condition usually caused by widespread dissemination of HSV-1 primary infection in a patient with pre-existing skin diseases, mostly atopic dermatitis, and presents as vesiculopustules on the trunk associated with fever and lymphadenopathy. These lesions progress to painful hemorrhagic, crusted erosions. Disease duration is about 2 weeks and lesions heal without scarring within 2-6 weeks. Eczema herpeticum is due to humoral and cellular immunity dysfunction: patients affected by diseases with skin barrier damage or immunodeficiencies are the most susceptible. Complications are due to bacterial infection (that can lead to sepsis) and to viremia with involvement of other organs $[7,8]$.

\section{- Varicella zoster virus}

\section{Shingles}

Reactivation of varicella zoster virus (VZV) after the primary infection (chickenpox) produces a classic unilateral dermatomal rash, generally limited to the skin area innervated by a single spinal/cranial sensory ganglion, with erythematous maculopapular lesions that quickly develop into vesicles and crusts. Burning pain, itching and paresthesias are often associated but herpes zoster may manifests as dermatomal pain or encephalitis without rash (zoster sine herpete), making the diagnosis more challenging [9]

\section{- Cytomegalovirus}

Cytomegalovirus (CMV) is a very common, usually unapparent, worldwide infection [10] that is transmitted from person to person via close contact with an individual excreting the virus. CMV can also be transmitted through oral/vaginal 


\begin{tabular}{|c|c|c|c|}
\hline Location & Histology & Clinical expression & Pathophysiology \\
\hline $\begin{array}{l}\text { Dermal capillary } \\
\text { endothelium }\end{array}$ & $\begin{array}{l}\text { Damage to vessel; endothelial swelling; } \\
\text { perivascular edema; hemorrhage; visualization of } \\
\text { organism by electron microscopy }\end{array}$ & $\begin{array}{l}\text { Macules, papules; } \\
\text { petechiae }\end{array}$ & $\begin{array}{l}\text { Direct effect of the virus/infectious agent; } \\
\text { immune response between infectious agent } \\
\text { and antibodies or cell-mediated response to it }\end{array}$ \\
\hline Dermis & $\begin{array}{l}\text { Edema; cellular infiltration; hemorrhage; } \\
\text { visualization of organism by electron microscopy }\end{array}$ & $\begin{array}{l}\text { Papules; urticaria; } \\
\text { purpura; vesicles }\end{array}$ & $\begin{array}{l}\text { Direct effect of the virus/infectious agent; } \\
\text { immune response between infectious agent } \\
\text { and antibodies or cell-mediated response to it; } \\
\text { histamine release }\end{array}$ \\
\hline Epidermis & $\begin{array}{l}\text { Visualization of organism by electron microscopy; } \\
\text { cytopathic effects induced by viruses (inclusions, } \\
\text { ballooning, vacuolation, necrosis) }\end{array}$ & $\begin{array}{l}\text { Papules; vesicles; } \\
\text { ulcer }\end{array}$ & Direct effect of the infectious agent \\
\hline
\end{tabular}

secretions, urine, semen, placenta, breast milk, blood transfusions and organ transplantation. Primary infection is followed by lifelong virus carriage with intermittent shedding in secretions. When symptoms appear they resemble infectious mononucleosis with fever and lymphadenopathy. In a third of cases, there is a follicular, maculopapular eruption, often affecting the legs (Figure 1) and lasting up to 2 days. Also urticarial and scarlatiniform eruption may occur. Small vessel lymphocytic vasculitis [11], GianottiCrosti syndrome (GCS) [12] and acute generalized exanthematous pustolosis (AGEP) [13] are other manifestations of CMV infection in immunocompetent patients. In immunosuppressed patients, a widespread papular/purpuric eruption with vesicobullous or pustular lesions and indurated pigmented nodules/plaques may appear. Sharply demarcated ulceration may occur, mostly around genitalia, perineum, buttocks and thighs. Keratotic skin lesions and mucosal/skin ulcerations have been reported in AIDS patients [10].

\section{- EBV}

EBV is a ubiquitous herpesvirus spread in childhood by contact with saliva. In all populations, the great majority of people are infected by middle age [14]. Skin lesions occur in $2-3 \%$ of patients with acute infectious mononucleosis. A faint morbilliform eruption lasting 24-48 h or a maculopapular rash occurring 7-10 days following ampicillin treatment are the most common manifestations, probably reflecting an enhanced reaction to drugs or their metabolites during the viral infection. Moreover, EBV infection has been related to GCS and unilateral laterothoracic exanthem in children [14], maculopapular atypical exanthems [1,3], AGEP [12], palmar eruption, erythema multiforme, urticaria vasculitis [1], drug reaction with eosinophilia and systemic symptoms (DRESS) [15] and genital ulcers in adults [1]. Eyelid and widespread petechiae, periorbital edema and maculopapular enanthem can also be noted [1]. Rarely, skin lesions are the presenting sign of the disease [16]. EBV-related skin diseases in immunodepressed patients include oral hairy leukoplakia and lymphoproliferative disorders [14].

\section{- Human herpesvirus 6 \& 7}

Commonly spread by saliva, human herpesvirus (HHV)-6 and HHV-7 usually causes a subclinical infection that persists lifelong $(90 \%$ of adults

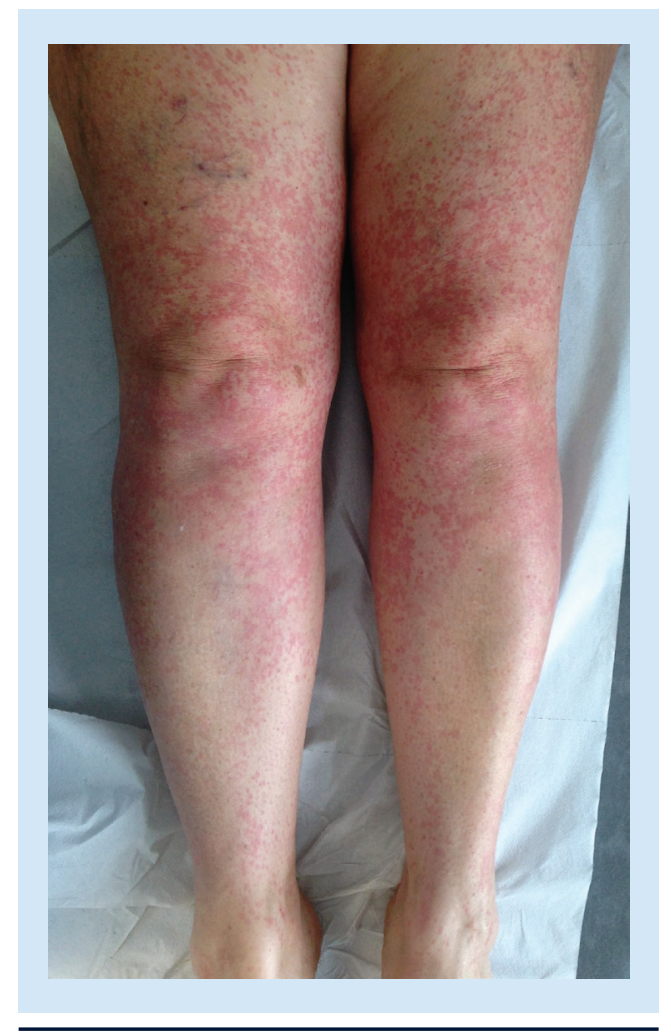

Figure 1. Maculopapular eruption affecting the legs due to cytomegalovirus infection. 
are seropositive). These viruses may cause exanthem subitum, the most common exanthematic fever in children under the age of 3 years, and are implicated in different cutaneous manifestations during their systemic reactivation [17]. Pityriasis rosea (PR) is an acute, self-limiting exanthematous disease associated to the endogenous systemic reactivation of HHV-6 and/or HHV-7. Although some authors have not been able to demonstrate this relationship [18,19], recent studies established a role for systemic active HHV-6 and $\mathrm{HHV}-7$ infection in the pathogenesis of PR, based on the detection of HHV-6 and HHV-7 DNA in plasma and their mRNA expression and specific antigens in skin lesions. In addition, herpesvirus virions in various stages of morphogenesis were detected by electron microscopy in skin lesions and in the supernatant of cocultured peripheral blood mononuclear cells from PR patients. The cytopathic effect and syncytia formation observed in peripheral blood mononuclear cell cultures from PR patients, HHV-6 and HHV-7 mRNA expression and antigens found in lesional skin are additional evidence of productive infection. Remarkably, HHV-6 and HHV-7 plasma viremia, a marker of systemic active infection, has been related to the presence of constitutional symptoms. On the basis of these studies, the association between HHV-6/7 and PR is considered definitive [20-24]. PR typically begins with a single, erythematous scaly plaque, followed by a secondary eruption consisting of smaller papulosquamous lesions on the cleavage lines of the trunk (Figure 2). Duration may vary from 2 to 10 weeks and constitutional symptoms may precede or accompany the eruption [23,24]. Maculopapular-petechial atypical PR may occur $[1,3,24]$. HHV-6 reactivation has been

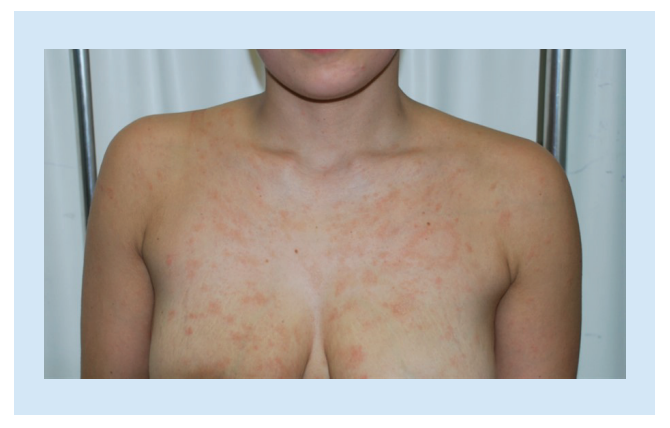

Figure 2. Pityriasis rosea: single, erythematous scaly plaque, followed by a secondary eruption consisting of smaller papulosquamous lesions on the cleavage lines of the trunk. described 2-3 weeks after organ transplantation, causing fever and maculopapular eruptions resembling acute graft-versus-host disease [25]. $\mathrm{HHV}-6 / 7$ reactivation has also been reported in DRESS (Figure 3) [26,27]. DRESS is a life-threatening multiorgan adverse drug reactions characterized by maculopapular rashes developing $>3$ weeks after starting with a limited number of drugs, prolonged clinical symptoms after discontinuation of the causative drug, fever $\left(>38^{\circ} \mathrm{C}\right)$, liver abnormalities (ALT $>100 \mathrm{U} / \mathrm{l}$ ), leukocyte abnormalities (at least one between leukocytosis [>11 $\times 109 / 1]$, atypical lymphocytosis [>5\%], eosinophilia [>1.5 × 109/1]), lymphadenopathy, HHV-6 reactivation [27]. Papular-purpuric gloves and socks syndrome [28] and GCS [29] have also been associated with HHV-6 infection.

\section{- Human herpesvirus 8}

HHV-8 seroprevalence greatly varies between geographic regions. Transmission mainly occurs through saliva or genital secretions. HHV-8 is etiologically associated with Kaposi's sarcoma (KS) and other proliferative diseases. Primary infection may be associated with a febrile maculopapular rash (median duration of 6 days) [30].

Erythematous rash has been described in an immunocompetent patient who had recurrent HHV-8 infection associated with a relapsing systemic inflammatory syndrome characterized by fever, lymphadenopathy, splenomegaly, edema and arthrosynovitis [31].

\section{- Parvovirus B19 (B19V)}

$\mathrm{B} 19 \mathrm{~V}$ is a DNA virus transmitted via the respiratory tract [32]. Seroprevalence increases with age up to $85 \%$ in adults. B19V infection differently manifests in different age groups and $20-50 \%$ of infections are asymptomatic. Erythema infectiousum (fifth disease) is the most common manifestation in children, whereas arthralgias and arthritis with or without rash are more common in adults $[32,33]$. A unique syndrome of pruritic erythema and edema with petechiae affecting hands and feet, called papular-purpuric gloves and socks syndrome, is often associated with florid B19V [34]. Sporadic association of this syndrome with other viruses (VZV, EBV, CMV, HHV-6/7, Coxsackie, hepatitis B virus and rubella) has been reported [35]. Moreover, B19V related maculopapular purpuric eruption involving trunk and limbs or inguinal folds and buttocks in a 'baboon-like' fashion have been recognized. Palms and soles are usually spared 
and when the eruptions have a reticulated appearance (Figure 4) they resemble erythema infectiousum [33].

\section{- Enteroviruses}

Enteroviruses includes Polioviruses 1, 2 and 3. Coxsackieviruses (A1-24 and B1-6), Echoviruses 1-34 and Enteroviruses 68-71. They inhabit the human alimentary tract and leave the host through throat secretions and feces; infection of the new host is acquired through oral cavity. Enteroviruses are the leading cause of exanthems in children, especially during summer and fall $[1,3]$. The incidence of exanthem is inversely related to age (more frequent in childhood) and there is marked variation in the clinical expression of the infection: the same virus may cause a different pattern of exanthem during the same epidemic and even in the same patient. Neurologic symptoms may develop simultaneously. Enteroviruses may determine maculopapular rash or hand-footmouth syndrome, often associated with systemic symptoms [1,3,36-37].

Coxsackieviruses, mainly A16, cause the hand-foot-mouth disease, that begins with low-grade fever and malaise. The presenting complaint is sore throat due to papulovesicular lesions that quickly erode and form shallow ulcerations (Figure 5). Shortly thereafter, peripheral vesicular lesions occurred on hands, feet and sometimes buttocks and genitalia with resolution in a week. Children are most frequently affected whereas adults may have an unapparent or aborted syndrome, the only visible manifestations occurring within the mouth, mistaken for aphthous stomatitis or HSV infection. Other oropharyngeal involvement without skin lesions caused by group A Coxsackievirus are herpangina [6] and acute lymphonodular pharyngitis [38]. Herpangina is characterized by fever, sore throat, vomiting and backache. Papulovesicular lesions occur in the soft palate and tonsils, progress to shallow ulcers and heal in a few days. Also group B Coxsackieviruses, Echoviruses, other Enteroviruses and Adenoviruses have been implicated. Acute lymphonodular pharyngitis presents with tiny nodules in the soft palate and tonsils which resolve without ulceration.

Coxsackieviruses can also cause diffuse maculopapular (mainly A9 and B5) or vesicular (mainly Coxsackieviruses A4, A9, A12) exanthems $[1,3]$ associated with fever and, rarely, with more severe manifestations (meningitis,

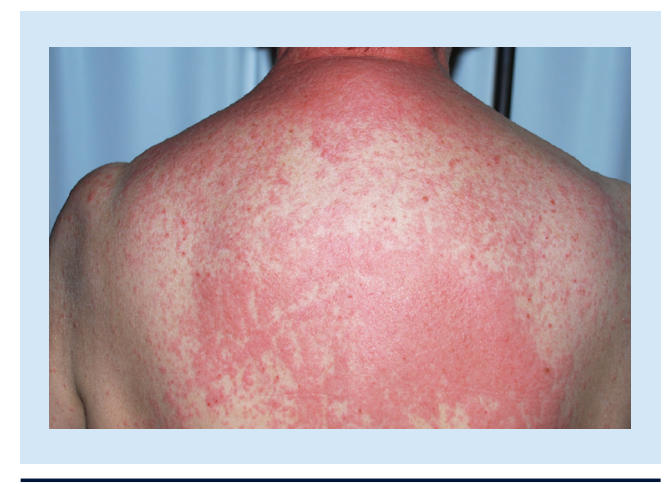

Figure 3. Maculopapular eruption of the trunk in drug reaction with eosinophilia and systemic symptoms associated with HHV-6 reactivation.

pneumonia, hepatitis). Eruptions due to coxsackie A4 and A9 begins on the face and trunk and occasionally spread centrifugally. A9 may also involve palms and soles [6,36]. The maculopapular eruption can progress, in case of A4 infection, becoming vesicular and may occur in crops with yellowish opaque vesicles. The lesions may mimic bug bites, but are no itchy. Conversely, in A9 vesicular exanthems, vesicles are clear resembling chickenpox. Coxsackie A9 may cause outbreaks of infection presenting with maculopapular exanthem and pneumonia [6,36]. Coxsackievirus A6 has been associated to a diffuse papular eruption extended over the whole body, with some papules evolving into vesiculobullous lesions and onychomadesis [37].

Coxsackievirus B4 and A9 have also been related to AGEP (see under specific paragraph). Coxsackievirus B2 and B3 infection cause vesicular rash and/or transient macular rash [6,38-39]. Coxsackievirus B6 may cause an eruption resembling papular-purpuric gloves and socks

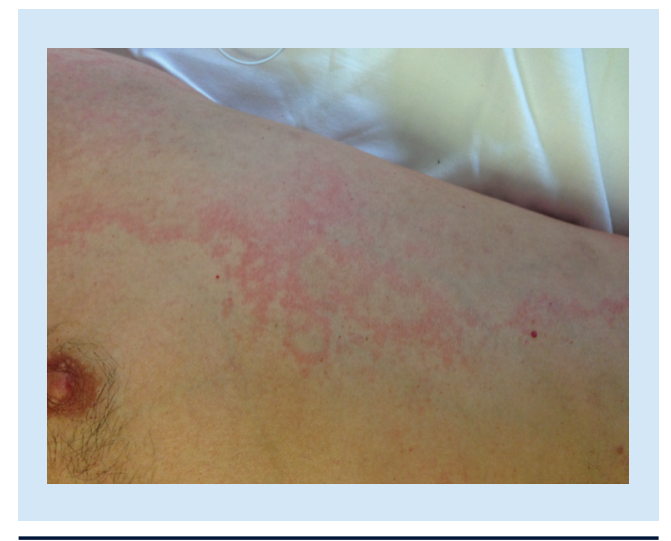

Figure 4. Parvovirus B19 infection: skin eruption have a reticulated appearance. 


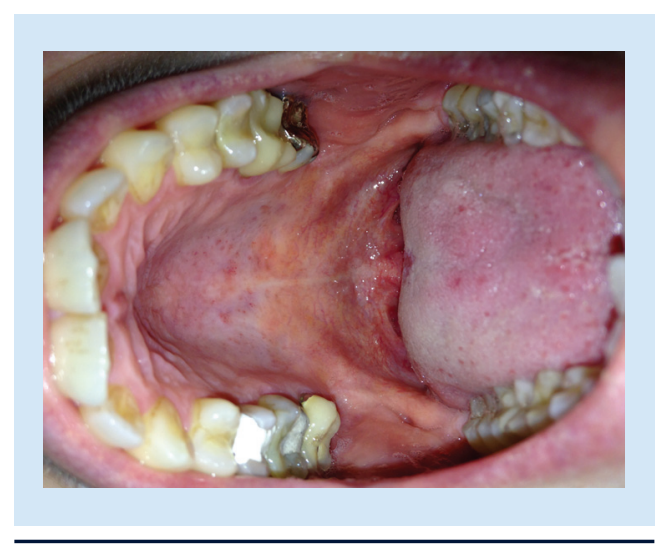

Figure 5. Enanthem in Coxsackievirus infection: papulovesicular lesions of the palate that quickly erode and form shallow ulcerations.

syndrome [40].

Echoviruses determined diffuse erythematous macular/maculopapular (Figure 6)/petechial rashes that may be associated with fever and/or meningitis starting on the face and upper trunk and spreading to the extremities. Echovirus 9 is the type most frequently found with fever, petechial eruption and signs of neurologic involvement that can mimic meningococcal meningitis or rickettsial disease. It can also cause erythematous macular localized eruptions (Figure 7) [41]. Echovirus 3 infection have been associated with petechial rash and meningitis [6]. Echovirus 11 infection can cause fever, pharyngitis, coryza and lymph nodes enlargement together with maculopapular/vesicular/urticarial rash. Skin lesions can be generalized or sparse and discrete, limited to extremities or to face and trunk [42]. Boston exanthem is a maculopapular/vesicular eruption involving face and trunk preceded by high fever caused by Echovirus 16 [43]. Enteroviruses, especially 25 and 32, have been associated with eruptive pseudoangiomatosis, a rare spontaneously regressing exanthem characterized by asymptomatic small, shiny red papules of angioma-like appearance surrounded by a characteristic pale halo. The lesions, often precede in children by fever, headache, vomiting, diarrhea or respiratory prodromal symptoms, involve checks and limbs with sudden onset resolving within a few days [44]. Echovirus 11 and 30 have also been linked with AGEP [13].

\section{- Adenoviruses \& other respiratory viruses}

Adenoviruses, including 51 serotypes, inhabit the tonsils and leave the infected host through throat secretions. They are overlooked as cause of eruptions that develop during a respiratory/ ocular infection. An exanthem associated with these infections occur primarily in children and occasionally in adults, during winter/spring. It manifests as a maculopapular [45] or vesicular exanthem beginning 1-2 days after the onset of fever and respiratory symptoms and characterized by centrifugal spread from the face toward the trunk and extremities $[1,3]$, resolving in 3-5 days. A petechial exanthem has also been described with adenovirus type 7 [46]. AGEP is another disease linked to adenovirus [14]. Exanthems have been described, especially in children, in association with other viruses responsible for respiratory illnesses (rhinoviruses, influenza A/B viruses, respiratory syncytial virus, parainfluenza viruses). They are more common than we though and usually mild and not very remarkable [36]. Moreover, co-infection with EBV/CMV and other respiratory agents may cause maculopapular rash and palatal petechiae [46] making it difficult to assign the cause of the rash.

Exanthem is uncommon during influenza viruses infection (2-8\% of patients), more frequent in children than adults [47]. It may be localized (face and hands) or generalized and described as macular/maculopapular, papular, petechial, itchy or not $[47,48]$. Respiratory infections lead to increased susceptibility to subsequent bacterial superinfection treated with antibiotics making difficult to distinguish between rash due to infection and allergic drug reaction. An erythematous macular rash due to respiratory syncytial virus might account for the so-called second attacks of measles or rubella [49].

\section{- Rotavirus}

Rotavirus infection is the most common cause of diarrhea in children worldwide. It may be accompanied by fever and vomiting followed by diarrhea and abdominal pain. An erythematous macular/maculopapular unnoticed exanthems lasting a few days may be present $[1,3]$.

\section{- GCS}

Initially described in association with hepatitis, GCS has now been linked to numerous etiologies: EBV, CMV, PVB19, Coxsackieviruses, influenza $\mathrm{A}$ virus and vaccinations. Worldwide, with the advent of hepatitis $B$ virus immunization, EBV is the most common cause of this exanthem. GCS primarily affects children (2-6 years of age) presenting as a papular/vesicular eruption, 
little or not itchy, that typically affects the extensor surfaces of upper/lower extremities, buttocks and face with truncal sparing. It may be accompanied by fever, hepatosplenomegaly and lymphadenopathy. GCS is self-limiting lasting for 3-5 weeks [12].

\section{- Eruptive hypomelanosis}

Zawar et al. [50] recently described a novel exanthem in nine Asian children presented with eruptions of hypopigmented macules following coryzal symptoms. The lesions were extrafacial, symmetric, of very similar sizes and were of acute onset without any personal or family history of atopic diathesis. Eruptive hypomelanosis has been related to a viral infection because of a prodromal coryzal phase 1-2 weeks preceding the lesions, the eruptive nature with one or more successive eruptions of lesions, the fairly uniform sizes of lesions and spontaneous resolution without action intervention. However, detection of viral DNA (respiratory viruses or other viruses) by PCR in the plasma, peripheral blood mononuclear cells and lesional biopsy specimens have not yet fully investigated. Moreover, acute and convalescent sera should be tested in parallel to detect rises of the IgG titers against a panel of viruses [50].

\section{- Superimposed lateralized exanthem}

Also known as 'asymmetrical periflexural exanthema of childhood,' superimposed lateralized exanthem is prevalent in childhood but several cases have been reported in adults. The eruption begins unilaterally, near the axilla or groin, with erythematous, maculopapular, slightly pruritic lesions that spread centrifugally and may become bilateral and scaly. The lesions usually resolve in 5 weeks with fine desquamation. The hypothesis explaining the unilateral preponderance is an increased responsiveness of a polygenic predisposed body side to various infectious agent: adenovirus, parainfluenza virus, PVB19, HHV-6/7 and EBV. Some of these viruses provide particular features to the exanthem, for example, PVB19 may be responsible for a purpuric pattern. An asymmetrical presentation may also be observed in PR [51] and some superimposed lateralized exanthem may be considered as atypical PR.

\section{- AGEP}

AGEP is a rare acute febrile eruption often associated with leucocytosis, characterized by small non follicular sterile pustules arising over

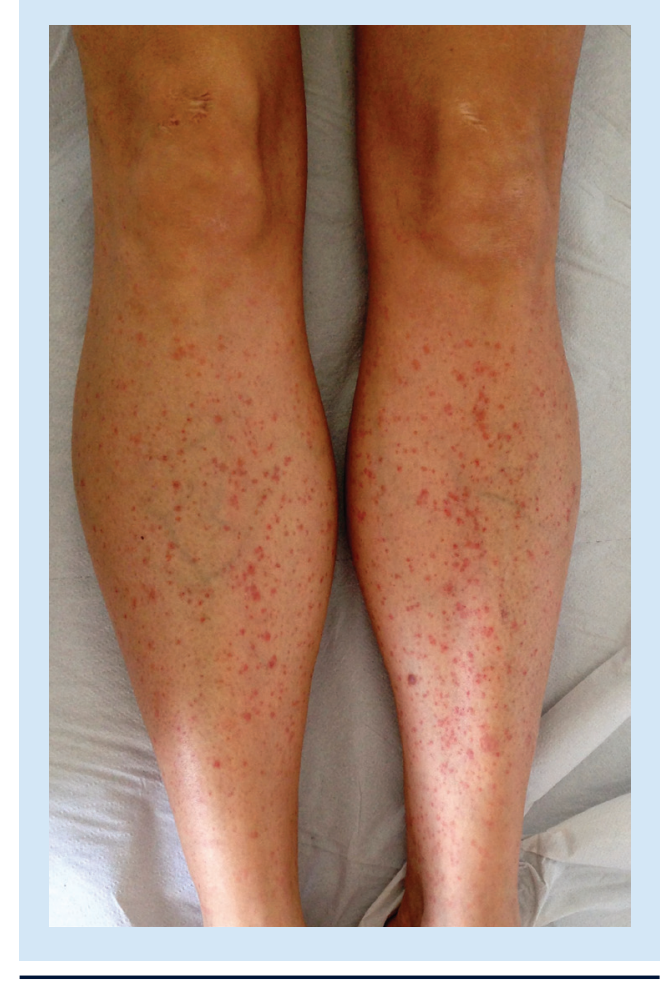

Figure 6. Maculopapular exanthem in Echovirus infection.

an edematous erythema. It affects mainly the upper trunk, folds and face resolving within 2 weeks with widespread desquamation. AGEP is usually drug induced but it may also be secondary to viral (enteroviruses, adenoviruses, CMV, EBV, hepatitis B virus) or bacterial (Chlamydia and mycoplasma) infections [13,52].

\section{- Hepatitis B \& C virus exanthems}

These viruses, whose transmission may be vertical, blood-borne or through sexual exposure, are uncommon causes of exanthems. Skin manifestations in acute infections include fine erythematous, macular reticular rash over trunk and limbs that resolves with the onset of jaundice

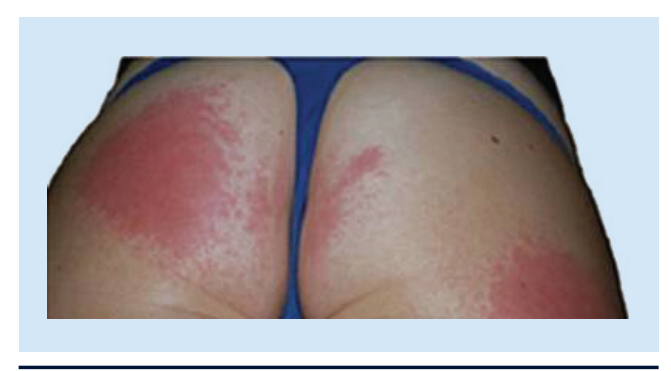

Figure 7. Erythematous macular localized eruptions in Echovirus infection. 


\section{Table 3. Arbovirus exanthems.}

\begin{tabular}{|c|c|c|c|c|c|}
\hline Virus & Geographical distribution & Presenting symptoms & $\begin{array}{l}\text { Timing from } \\
\text { symptoms to } \\
\text { rash }\end{array}$ & Exanthem features & $\begin{array}{l}\text { Patients with } \\
\text { exanthem }\end{array}$ \\
\hline Dengue fever & $\begin{array}{l}\text { Central/South America, } \\
\text { sub-Saharan Africa, Asia }\end{array}$ & $\begin{array}{l}\text { Fever, chills, headache, } \\
\text { vomiting, myalgia/arthralgia }\end{array}$ & $3-5$ days & $\begin{array}{l}\text { Maculopapular eruption } \\
\text { with islands of sparing; } \\
\text { possible petechiae and } \\
\text { purpura }\end{array}$ & $83 \%$ \\
\hline $\begin{array}{l}\text { Dengue } \\
\text { hemorrhagic } \\
\text { fever }\end{array}$ & $\begin{array}{l}\text { Central/South America, } \\
\text { sub-Saharan Africa, South } \\
\text { Central/Southeast Asia }\end{array}$ & High fever, vomiting, nausea & 2-3 days & Petechiae and purpura & $100 \%$ \\
\hline West Nile fever & Widespread & $\begin{array}{l}\text { Fever, headache, } \\
\text { photophobia, myalgia, } \\
\text { arthralgia }\end{array}$ & $3-12$ days & $\begin{array}{l}\text { Macular/maculopapular rash } \\
\text { on extremities and trunk; }\end{array}$ & $20 \%$ \\
\hline Rift Valley fever & $\begin{array}{l}\text { Southeastern/western/ } \\
\text { northern Africa, } \\
\text { Madagascar, Yemen }\end{array}$ & $\begin{array}{l}\text { Fever, myalgia, dizziness, } \\
\text { headache, mood swings, } \\
\text { tachycardia }\end{array}$ & 2-4 days & $\begin{array}{l}\text { Petechial rash and/or a } \\
\text { petechial enanthema, } \\
\text { involving mouth and/or } \\
\text { throat }\end{array}$ & $1 \%$ \\
\hline Sandfly fever & $\begin{array}{l}\text { Mediterranean Africa and } \\
\text { Europe, Central Africa and } \\
\text { Central Asia }\end{array}$ & $\begin{array}{l}\text { Fever, chills, headache, } \\
\text { myalgia, possible abdominal } \\
\text { pain, diarrhea }\end{array}$ & Concomitant & $\begin{array}{l}\text { Flushing erythema on face } \\
\text { and neck; rarely subsequent } \\
\text { macular rash }\end{array}$ & $\begin{array}{l}\text { Frequent but no } \\
\text { clear reference in } \\
\text { the literature }\end{array}$ \\
\hline $\begin{array}{l}\text { Chikungunya } \\
\text { fever }\end{array}$ & $\begin{array}{l}\text { Sub-Saharian Africa, India, } \\
\text { Southeastern Asia }\end{array}$ & $\begin{array}{l}\text { Biphasic fever, headache, } \\
\text { myalgia, phtophobia, } \\
\text { vomiting }\end{array}$ & 4-5 days & $\begin{array}{l}\text { Maculopapular rash on } \\
\text { extremities and trunk }\end{array}$ & $40-50 \%$ \\
\hline $\begin{array}{l}\text { O'nyong-nyong } \\
\text { fever }\end{array}$ & Uganda, Tanzania, Kenya & Fever and polyarthralgia & $2-4$ days & $\begin{array}{l}\text { Maculopapular exanthem } \\
\text { on trunk and extremities }\end{array}$ & $70 \%$ \\
\hline Mayaro fever & Brazil, Colombia & $\begin{array}{l}\text { Fever, chills, headache, } \\
\text { arthralgia }\end{array}$ & 5 days & $\begin{array}{l}\text { Maculopapular rash on } \\
\text { trunk and limbs, possible } \\
\text { petechial manifestation }\end{array}$ & $24-67 \%$ \\
\hline Ross river fever & Australia, Nuova Guinea & $\begin{array}{l}\text { Mild fever, myalgia, } \\
\text { arthralgia }\end{array}$ & 5 days & $\begin{array}{l}\text { Maculopapular rash on } \\
\text { trunk and limbs }\end{array}$ & $50-60 \%$ \\
\hline $\begin{array}{l}\text { Barmah Forest } \\
\text { virus infection }\end{array}$ & Australia & Fever, lethargy, arthralgia & $2-5$ days & $\begin{array}{l}\text { Maculopapular/vesicular/ } \\
\text { purpuric eruption on trunk, } \\
\text { limbs and face }\end{array}$ & $70 \%$ \\
\hline Sindbis virus & $\begin{array}{l}\text { Africa, Asia, northern } \\
\text { Europe }\end{array}$ & Fever, myalgia, arthralgia & 2-10 days & $\begin{array}{l}\text { Itchy papular rash on trunk } \\
\text { and limbs }\end{array}$ & $96 \%$ \\
\hline $\begin{array}{l}\text { Colorado tick } \\
\text { fever }\end{array}$ & USA, Canada, Mexico & $\begin{array}{l}\text { Biphasic fever, headache, } \\
\text { myalgia, ocular disorders }\end{array}$ & 4 days & $\begin{array}{l}\text { Evanescent macular rash on } \\
\text { trunk and limbs }\end{array}$ & $5-15 \%$ \\
\hline Zika virus & Africa, southeast Asia & $\begin{array}{l}\text { Fever, headache, fatigue, } \\
\text { aphthous ulcers, arthralgyas }\end{array}$ & Concomitant & Maculopapular on trunk & $80 \%$ \\
\hline
\end{tabular}

after a few days to 4 weeks [53]. Hepatitis B virus infection has also been associated with AGEP [13].

\section{- HIV}

HIV transmission can occur through blood transfusions, organ transplantation, transplacentally and mostly through heterosexual/ homosexual relationships. Cutaneous eruptions may be due to HIV per se or from other infectious and noninfectious causes. HIV seroconversion illness may be associated with a nonpruritic generalized maculopapular rash involving trunk, hands and feet sometimes associated with painful oral/genital erosions. Moreover, in HIV-patients, HHV-8 can cause $\mathrm{KS}$, which manifests as angiomatous macules, plaques or nodules. Multicentric Castleman's disease associated with HHV-8 infection can also result in a recurrent maculopapular rash on limbs and trunk [54].

\section{- Arboviruses \& tropical fevers}

Arboviruses are transmitted to humans by arthropods and maintained in nature by biological cycles involving a susceptible vertebrate host reservoir and hematophagous arthropods vectors. Arboviruses generally have an enzootic cycle and 
only accidentally infect humans. However, for dengue virus or sandfly fever virus, humans are the natural vertebrate host. In these cases infections are endemic or epidemic if the arthropod vector is abundant. In arboviruses infections, more than half of the patients present a skin rash. The exanthem type varies according to the arbovirus and usually develops 1-12 days after the onset of fever, headache, conjunctival injection and arthromyalgias (Table 3) [55-59]. Nowadays, chikungunya virus and Zika virus are emerging pathogens that are spreading widely in different parts of the world. In chikungunya infection, a maculopapular rash of the trunk and extremities may be seen in more than $50 \%$ of the patients, sometimes associated with oral ulcers. The rash may evolve into petechiae, urticaria, xerosis or hypermelanosis and gradually fades in about 1 week. Some of the symptoms and signs of chikungunya infection are almost indistinguishable from those of dengue infection [60,61]. In Zika virus infection a diffuse maculopapular rash may be observed in up to $98 \%$ of the patient also in association with conjunctivitis and edema of hands and feet lasting only a few days [62-64]. Clinicians should include these exanthems in the differential diagnosis of patients who presented with fever, polyarthralgia and skin rash, especially if there is a recent history of travels to and from epidemic areas (Americas and India for chikungunya; Brasil for Zika virus).

\section{- Viral hemorrhagic fevers}

In viral hemorrhagic fevers skin and mucous membranes are the first sites where hemorrhagic manifestations are visible. Petechial/purpuric eruptions, ecchymosis, enanthem and mucosal bleeding are common features that occur usually 1 week after the onset of symptoms (fever, chills, myalgia, vomiting). Depending on the type of fever, there may be peculiar cutaneous manifestations that can orient in the diagnostic process. Dermatological signs may be helpful for a prompt diagnosis in febrile patients returning from endemic areas (South America or Africa) (Table 4) [65,66].

\section{Bacterial exanthems}

\section{- Scarlet fever}

Scarlet fever has been described in Table 1.

\section{Toxic shock syndromes}

Toxic shock syndromes (TSSs) are life-threatening illnesses caused by Streptococcus pyogenes (group A) or Staphylococcus aureus infection. Their virulence is mainly due to the production of circulating toxins, which often function as superantigens in causing clinical manifestations, morbidity and mortality associated with these diseases. The initial infectious outbreak may be localized in the skin, soft tissues, vagina or a surgical wound. The hallmarks of TSSs are high fever, myalgia, vomiting, diarrhea, headache and nonfocal neurologic abnormalities accompanying a macular erythroderma followed by desquamation, hypotension and multiple-organ involvement. Erythema and edema of palms and soles and scarlatiniform flexural accentuation of the rash are frequently observed. Petechial hemorrhages, mucous membranes hyperemia and strawberry tongue are often noted. Disseminated intravascular coagulation may supervene. TSSs usually complicate the use of absorbent tampons, barrier contraceptives, surgical and postpartum wound infections, burns, cutaneous lesions, osteomyelitis and arthritis [67].

\section{- Rickettsial exanthems}

Rickettsioses are worldwide-distributed zoonoses caused by obligate intracellular Gramnegative bacteria which have marked tropism for endothelial cells of small vessels. Rickettsiae are transmitted by arthropods to vertebrates via salivary secretions or feces. Rickettsial diseases vary in severity from self-limited mild illnesses to fulminating life-threatening infections and their main symptoms are fever, headache and cutaneous eruptions [68]. Cutaneous eruptions occur in almost $100 \%$ of the rickettsiosis.

Rocky Mountain spotted fever, widespread in all American countries, is caused by Rickettsia rickettsii, transmitted to humans by the bite of infected ticks.

It is considered the most severe rickettsiosis, since it can be lethal even in healthy people. After the incubation period (5-10 days), patients complain of fever, chills, conjunctival injection, myalgias and headache followed, 3 days after onset, by a macular rash starting on the wrists (Figure 8) [69] and ankles as small, not itchy pink lesions that become maculopapular with extension to extremities, buttocks, face and trunk. In a few days, petechial/purpuric lesions supervene which may coalesce to form large hemorrhagic areas. Up to $10 \%$ of the patients have no rash (Rocky Mountain 'spotless' fever). Eschars may be present. The disease recover in 2-3 weeks but in untreated cases fatality is high (20-50\%) [68]. 
Table 4. Viral hemorrhagic fevers.

\begin{tabular}{|c|c|c|c|c|}
\hline Virus type & Disease & $\begin{array}{l}\text { Geographical } \\
\text { distribution }\end{array}$ & Presenting symptoms & $\begin{array}{l}\text { Exanthem features and associated signs/ } \\
\text { symptoms }\end{array}$ \\
\hline Lassa virus & Lassa fever & West Africa & Fever, chills, headache & $\begin{array}{l}\text { Disseminated nonpalpable petechiae } \\
\text { and purpura; conjunctivitis, oral ulcers, } \\
\text { pharyngitis, facial edema }\end{array}$ \\
\hline Junin virus & $\begin{array}{l}\text { Argentine hemorrhagic } \\
\text { fever }\end{array}$ & Argentina & Fever, myalgia & $\begin{array}{l}\text { Erythema of the face and trunk; conjunctival } \\
\text { inection; petechiae on the trunk; petechial } \\
\text { enanthem }\end{array}$ \\
\hline Machupo virus & $\begin{array}{l}\text { Bolivian hemorrhagic } \\
\text { fever }\end{array}$ & Bolivia & Fever, headache, arthralgia & Diffuse petechiae, mucosal bleeding \\
\hline Guanarito virus & $\begin{array}{l}\text { Venezuelan } \\
\text { hemorrhagic fever }\end{array}$ & Venezuela & $\begin{array}{l}\text { Fever, headache, myalgia, } \\
\text { arthralgia }\end{array}$ & Diffuse petechiae, mucosal bleeding \\
\hline Sabià virus & $\begin{array}{l}\text { Brazilian hemorrhagic } \\
\text { fever }\end{array}$ & Brazil & $\begin{array}{l}\text { Fever, headache, myalgia, } \\
\text { arthralgia }\end{array}$ & Diffuse petechiae, mucosal bleeding \\
\hline $\begin{array}{l}\text { Hantaviruses: } \\
\text { Hantaan, Seoul, } \\
\text { Dobrava-Belgrade, } \\
\text { Saaremaa }\end{array}$ & $\begin{array}{l}\text { Hantavirus syndrome } \\
\text { (renal syndrome) }\end{array}$ & $\begin{array}{l}\text { Eastern Asia; } \\
\text { western and } \\
\text { central Europe } \\
\text { but Seoul virus } \\
\text { worldwide }\end{array}$ & $\begin{array}{l}\text { Fever, myalgia, nausea, } \\
\text { vomiting, conjuntival } \\
\text { irritation }\end{array}$ & $\begin{array}{l}\text { Erythematous-petechial rash on face, neck, } \\
\text { shoulders, chest }\end{array}$ \\
\hline $\begin{array}{l}\text { Crimean-Congo } \\
\text { virus }\end{array}$ & $\begin{array}{l}\text { Crimean-Congo } \\
\text { hemorrhagic fever }\end{array}$ & $\begin{array}{l}\text { Africa, the } \\
\text { Balkans, the } \\
\text { Middle East and } \\
\text { Asian countries }\end{array}$ & $\begin{array}{l}\text { Fever, myalgia, dizziness, } \\
\text { stiffness, vomiting, } \\
\text { agitation followed by } \\
\text { sleepiness, depression }\end{array}$ & $\begin{array}{l}\text { Petechiae that widen into large ecchymosis, } \\
\text { petechial enanthem }\end{array}$ \\
\hline Marburg virus & $\begin{array}{l}\text { Marburg hemorrhagic } \\
\text { fever }\end{array}$ & Africa & $\begin{array}{l}\text { Fever, myalgia, severe } \\
\text { prostration }\end{array}$ & Maculopapular rash and petechial enanthem \\
\hline Ebola virus & Ebola virus disease & $\begin{array}{l}\text { West and } \\
\text { central Africa }\end{array}$ & $\begin{array}{l}\text { Fever, myalgia, sore } \\
\text { throat; subsequently } \\
\text { gastrointestinal signs }\end{array}$ & $\begin{array}{l}\text { Maculopapular rash, petechiae, purpura, } \\
\text { ecchymosis; oral-throat fissured lesions, } \\
\text { gengival bleeding }\end{array}$ \\
\hline Dengue virus & Dengue fever & $\begin{array}{l}\text { Southeastern } \\
\text { Asia, Africa, } \\
\text { Mediterranean } \\
\text { Europe }\end{array}$ & $\begin{array}{l}\text { Fever, conjuntival injection, } \\
\text { arthromyalgias }\end{array}$ & $\begin{array}{l}\text { Maculopapular rash with petechiae during } \\
\text { defervescence (favorable evolution) }\end{array}$ \\
\hline Dengue virus & $\begin{array}{l}\text { Dengue hemorrhagic } \\
\text { fever }\end{array}$ & $\begin{array}{l}\text { Central Asia, } \\
\text { Central/South } \\
\text { America }\end{array}$ & $\begin{array}{l}\text { Fever, conjuntival injection, } \\
\text { arthromyalgias }\end{array}$ & $\begin{array}{l}\text { Maculopapular rash with petechiae during } \\
\text { defervescence; hypotension, tachycardia, } \\
\text { cyanosis }\end{array}$ \\
\hline $\begin{array}{l}\text { Omsk hemorrhagic } \\
\text { disease virus }\end{array}$ & $\begin{array}{l}\text { Omsk hemorrhagic } \\
\text { disease }\end{array}$ & Siberia & $\begin{array}{l}\text { Fever, myalgia, occipital } \\
\text { rigidity, loss of taste, } \\
\text { decrease in hearing }\end{array}$ & Petechial rash and petechial enanthem \\
\hline $\begin{array}{l}\text { Kyasanur forest } \\
\text { virus }\end{array}$ & $\begin{array}{l}\text { Kyasanur forest } \\
\text { hemorrhagic fever }\end{array}$ & $\begin{array}{l}\text { India, Saudi } \\
\text { Arabia }\end{array}$ & $\begin{array}{l}\text { Severe headache, mental } \\
\text { disturbance, tremors, } \\
\text { rigidity, photophobia }\end{array}$ & $\begin{array}{l}\text { Suffusion of the conjuntiva, petechial } \\
\text { hemorrhages on the mucous membranes, } \\
\text { bleeding from nose, mouth }\end{array}$ \\
\hline
\end{tabular}

Epidemic typhus is caused by Rickettsia prowazekii, transmitted worldwide by body louses and by flying squirrel in the USA. The incubation period lasts 10-14 days and the exanthem occurs 5-7 days after appearance of systemic symptoms (fever, myalgias and sensory impairment). It has a centrifugal distribution, starting on the trunk and spreading to the extremities without palmoplantar and face involvement. The early rash consists of pink macules which fades when you press on it. Later, the rash becomes maculopapular and does not fade. The disease is fatal in $10-30 \%$ of patients. After some years from acute infection, $R$. prowazekii can reactivate and cause a recurrent form of epidemic typhus known as Brill-Zinsser disease: adipose tissue has recently been discovered in humans as reservoir for Rickettsiae [68].

Murine typhus is an acute febrile illness diffuse in tropical/subtropical regions caused by Rickettsia Typhi and Rickettsia felis transmitted by the fleas of rodents. The incubation time is 7-14 days. Signs/symptoms include fever, rash and arthralgia. The rash is macular/maculopapular, nonpruritic, starting on the trunk and spreading peripherally [68]. 
Mediterranean spotted fever, Rickettsialpox and Tsutsugamushi are acute febrile illness presenting with or without rash. The most common sign of infection is the inoculation eschar.

Mediterranean spotted fever, the most frequent rickettsiosis in Europe, is caused by $R$. conorii, transmitted by the brown dog tick. Sometimes conjunctivitis might represent the eye-inoculation site occurring after the manipulation of crushed infected ticks. After an incubation period of $5-7$ days, the onset of fever $\left(39-40^{\circ} \mathrm{C}\right)$ is accompanied by conjunctival injection, headache, photophobia and arthralgias. With the onset of fever, a small ulcer (tache noire) appears at the site of the tick bite: it has a necrotic center surrounded by erythematous skin and is associated with regional lymphnodes enlargement. On the 4th day of fever, a maculopapular/petechial exanthem appears on the forearms and extends to the body, involving face, palms and soles [68]. A vesicopustular rash has also been described [70]. Fever lasts into the 2nd week and the rash fades slowly.

Rickettsialpox, widespread worldwide, is caused by Rickettsia akari transmitted by the bite of the house-mouse mite. A papulovesicular lesion, $24-48 \mathrm{~h}$ after the bit, is the first manifestation evolving later in a crusted, ulcerated papule (eschar) with a red halo associated with regional lymphadenopathy. After a few days, fever, chills, photophobia, headache and myalgia begin followed by 2-3 days by a papulovesicular eruption on face, trunk and extremities and by a vesicular enanthem.

The vesicles can develop in pustules that later crust and resolve in a week. Rickettsialpox can resemble chickenpox but in chickenpox the vesicles are larger and surrounded by erythema in a 'dewdrop on a rose petal' fashion. Unlike chickenpox, the Tzank test does not show multinucleated giant cells and fever precedes the eruption.

Scrub typhus is caused by Orientia Tsutsugamushi (formerly Rickettsia Tsutsugamushi), following the bite of infected mite vectors. One to 2 weeks after the bite fever, chills, conjunctival injection, headache, myalgia, diarrhea and generalized lymphadenopathy suddenly start and an eschar develops at the bite site. A centrifugal maculopapular eruption primarily involving the trunk and extending to arms and legs may occur, fading within a few days [68].

\section{- Anaplasma \& erlichia}

Anaplasma phagocytophilum and Ehrlichia chaffeensis are the etiologic causes of anaplasmosis and herlichiosis, tick-borne diseases that are widespread in the USA. Accompanying fever, headache, myalgias, arthralgias, vomiting and cough, a rash is present in less than $10 \%$ of Anaplasmosis and in 30\% of Erlichiosis. The rash is maculopapular or petechial involving the trunk and sparing palms and soles [71].

\section{- Syphilitic roseola}

Secondary syphilis is the stage in which generalized manifestations occur on the skin and mucous membranes. Patients may complain of constitutional symptoms but the majority of them have only skin rash and generalized lymphadenopathy. Eruptions develop in $80-95 \%$ of cases, occurring within 3 months from initial infection and may mimic other exanthems. A fading symmetrical, pink or coppery-red, nonitching macular eruption (roseola syphilitica) that follows on the back the lines of cleavage may pass unnoticed and maculopapules may be the first sign of the diseases (Figure 9). The lesions have a scaly surface with a squamous ring (Biet's collarette). Palms and soles may be involved with more pronounced papulosquamous lesions. Vesicular and pustular lesions are rare. Papules may coalesce into gray patch with erosions covered by macerated scales on the oral mucosa, tongue or tonsillae [72].

\section{- Neisseria meningitidis}

The skin lesions associated with meningococcemia and meningococcal meningitis, occurring in $40-90 \%$ of cases, result from damage of small dermal blood vessels. Transient erythematous macular/maculopapular eruptions involving any part of the body are seen but a purpuric eruptions on trunk and limbs is typical.

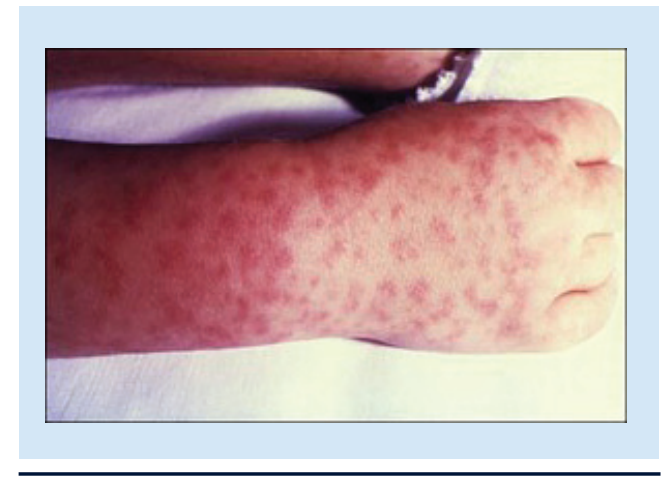

Figure 8. Macular rash starting on the wrists in Rocky Mountain spotted fever.

Adapted with permission from the CDC [69]. 


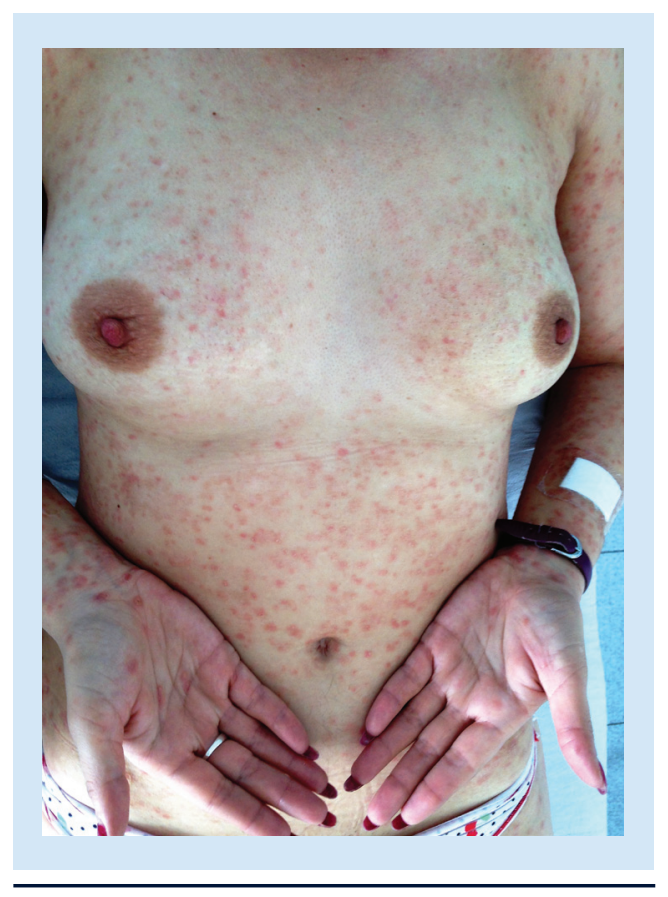

Figure 9. Symmetrical, pink/erythematous, nonitching macular eruption (roseola syphilitica).

The petechiae may also affect the mucous membranes (meningococcal conjunctivitis) and have a subungual location. Similar lesions can be caused in other bacterial meningitis due to Streptococcus pneumoniae, hemophilus influenza and listeria monocytogenes [73]. Meningococcemia may be in differential diagnosis with enteroviral infections in the presence of a patient, especially a child, with fever, headache, petechial exanthem and neck stiffness. Furthermore, no child with a rash confined to the distribution of the superior vena cava (petechiae above the nipple line) had meningococcal infection. In adults with bacterial meningitis rash is present in $26 \%$ but almost all had at least two of the four following symptoms: fever, headache, neck stiffness and changes in mental status [74].

\section{- Neisseria gonorrhea}

Neisseria gonorrhea is a Gram-negative diplococcus that cause gonorrhea and occasionally disseminated infections. However most patients with septic gonococcal infection have no symptoms indicating a sexually transmitted disease [75]. Bacteremic dissemination is regularly associated with arthralgia and skin lesions (arthritisdermatitis syndrome), occurs in $1-3 \%$ of the patients and usually develops within 2-3 weeks from the primary infection. Neisseria gonorrhea spread from a primary site, such as endocervix, urethra, pharynx or rectum, and disseminate to the blood to infect any organs. Patients may present with rash, fever, arthralgias, migratory polyarthritis, septic arthritis, tenosynovitis; meningitis, endocarditis or osteomyelitis are rare. The skin lesions, present in $60 \%$ of the patients, are few in number $(<20$ lesions) but are a crucial diagnostic sign. There may be violaceous macular/maculopapular/vesicular lesions with a dusky red halo evolving into pustules and bullae that may become hemorrhagic or necrotic. Purpuric lesions and subcutaneous painful nodules may be present. Urticarial lesions and erythema multiforme has also been reported. The lesions, which predominate on the trunk and limbs including fingers, palms and soles, may be in various stages of evolution resolving over a few days without scars [75].

\section{- Staphylococcus aureus}

Staphylococcus aureus from pyodermas, soft tissue infections or medical devices can invade lymphatic and blood vessels resulting in dissemination of the infection at distant sites. In acute $S$. aureus endocarditis and bacteremia, skin and mucous membranes lesions occur in the majority of patients and provide a clue to the diagnosis. Petechial eruption occurring in crops affects mainly the extremities (including palms and soles) and oral mucous membranes and conjunctivae. These eruptions as well as splinter hemorrhages (subungueal hemorrhages), Osler's nodules (erythematous, painful nodules over the limbs, palms, soles and on the pads of the fingers and toes) and Janeway lesions (erythematous macules/papules on palms and soles) are common in bacteremia and endocarditis due to streptococci, enterococci and gonococci [76]. These eruptions can be the overture of hemorrhagic infarction and necrosis of the skin due to disseminated intravascular coagulation. In focal infections, erythematous macular/maculopapular eruptions are described [1].

\section{- Enterobacteriaceae}

Enterobacteriaceae is a family of Gram-negative bacteria that are residents of the GI tract including Escherichia, Klebsiella, Salmonella, Shigella, Proteus, Enterobacter and Yersinia. They may cause sepsis, lower respiratory tract infections, endocarditis and infections of CNS, skin and soft tissues, urinary tract, joints, bones and eyes. 
Escherichia coli cause maculopapular [1,3] and localized macular exanthems during urinary infections and perinephric abscess.

Klebsiella pneumoniae may colonize the skin, pharynx or GI tract. The hands of hospital personnel can spread rapidly the infection leading to nosocomial outbreaks. The spectrum of clinical syndromes includes pneumonia, bacteremia, urinary tract infections, cholecystitis, diarrhea, wound infections, osteomyelitis and meningitis. Skin eruptions caused by Gram-negative bacteria is uncommon in newborns but Klebsiella may cause maculopapular exanthems arising during septicemia [77].

Salmonella typhi can cause the so-called 'rose spots,' pink maculopapules which arise in crops of 10-20 lesions on the anterior trunk, fading in a few days [78].

Shigella species cause bacillary dysentery and, mainly in children and immunocompromised patients, also extragastrointestinal complications (septicaemia, neurologic involvement). Rose spots, resembling salmonella infections, have been described [79].

Yersinia enterocolitica and Yersinia pseudotuberculosis are zoonosis acquired by ingestion of contaminated food/water which occur worldwide. Yersinia enterocolitica is a common cause of diarrheal disease and mesenteric adenitis that clinically mimics appendicitis, whereas $Y$. pseudotuberculosis most commonly causes mesenteric adenitis. Both species can cause pharyngitis, septicemia, focal infections in multiple organs, postinfectious erythema nodosum and reactive arthritis. During yersiniosis a scarlet fever-like illness and maculopapular, papulovesicular, erythema multiforme-like eruptions have been described [80].

\section{- Other bacteria (miscellanea)}

Maculopapular eruptions involving mainly the trunk may be caused by Chlamydia psittaci and trachomatis, Arcanobacterium hemoliticum, Streptococcus pyogenes [1], Streptococcus dysagalactiae [81], Borrelia burgdorferi and Haemophilus influenzae [1]. Mycoplasma pneumoniae is a common cause of community acquired pneumonia which may be responsible for mucocutaneous lesions associated with systemic infection [82]. Prodromal symptoms (cough and fever) usually precede the skin eruption with vesico-bullae followed by maculopapular lesions [36]. An acral distribution of the exanthem is frequent. Oral lesions often accompany the cutaneous eruptions and in a third of patients are not associated with skin involvement.

Disseminated pruritic papules and pustules (hot tub folliculitis) may arise on the trunk and limbs immersed in community heated wading pool, swimming pools, whirlpool, hot tubes or after-diving suit dressing contaminated by Pseudomonas aeruginosa (Figure 10). In addition, painful erythematous nodules may develop on the soles immersed in contaminated wading pool [83].

Bartonella henselae and Bartonella Quintana are Gram-negative bacteria which cause bacillary angiomatosis, vascular purple papules or bleed nodules arising on the trunk and limbs, occurring most commonly in immunocompromised patients. Papules and nodules can group in indurated plaques resembling pyogenic granuloma or KS. Subcutaneous nodules and visceral lesions may occur. The patient may complain of chills, headache, fever and anorexia and the lesions may be few or hundreds [84]. Brucella species cause a zoonotic infection which is endemic in Mediterranean countries. Skin involvement is rare but disseminated macular rash on the trunk and extremities have been described [85].

Legionella pneumophila is a Gram-negative bacillus, that may cause pneumonia in adults. The term Legionnaires' disease is given to the severe pneumonia and systemic infections presenting with fever, headache, nausea, diarrhea, abdominal pain and myalgias, caused by Legionella. Legionella species affect susceptible patients as a result of age (patients $<1$ year or elderly), underlying debilitating conditions or immunosuppression. During pneumonia, maculopapular eruption and pretibial erythema have been described [86].

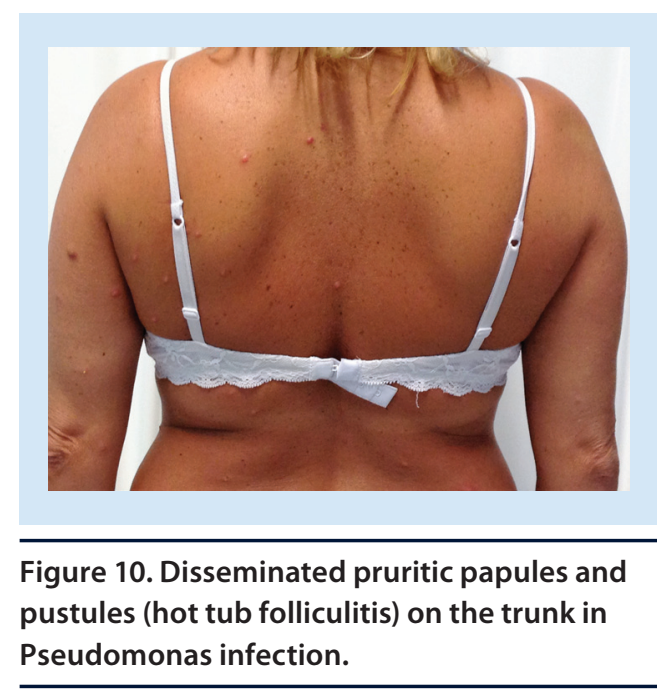


Table 5. Common infectious agents causing exanthems and enanthems: morphology of the skin and mucosal lesions.

\begin{tabular}{|c|c|c|c|}
\hline Agent & Disease & Exanthem morphology & Enanthem morphology \\
\hline \multicolumn{4}{|l|}{ Viruses } \\
\hline Herpes simplex virus $1 / 2$ & Herpes labialis/genitalis & \multicolumn{2}{|c|}{$\begin{array}{l}\text { Grouped vesicular lesions in orolabial or genital areas } \\
\text { evolvinging to erosions }\end{array}$} \\
\hline Herpes simplex virus 1 & Eczema herpeticum & \multicolumn{2}{|c|}{$\begin{array}{l}\text { Vesiculopustules on the upper part of the body evolving to } \\
\text { painful hemorrhagic, crusted erosions. }\end{array}$} \\
\hline Varicella zoster virus & Shingles & \multicolumn{2}{|c|}{$\begin{array}{l}\text { Unilateral erythematous maculopapular lesions that quickly } \\
\text { develop into grouped vesicles and crusts }\end{array}$} \\
\hline Citomegalovirus & $\begin{array}{l}\text { Mononucleosis; atypical exanthems; } \\
\text { GCS }\end{array}$ & $\begin{array}{l}\text { MP, U pattern in immunocompetent; } \\
\mathrm{P}, \mathrm{PE}, \mathrm{VB}, \mathrm{PU} \text { in immunosuppressed }\end{array}$ & MPP \\
\hline Epstein-Barr virus & $\begin{array}{l}\text { Mononucleosis; atypical exanthems; } \\
\text { GCS; APEC; AGEP }\end{array}$ & MP; U; PE & MP \\
\hline Human herpes virus 6 and 7 & $\begin{array}{l}\text { Pityriasis rosea; atypical exanthems; } \\
\text { DRESS; GCS; APEC }\end{array}$ & M; MP; MPP & M; MP; MPP \\
\hline Human herpes virus 8 & Atypical exanthems & MP & MP \\
\hline Parvovirus B 19 & $\begin{array}{l}\text { Fifth disease; atypical exanthems; } \\
\text { GCS }\end{array}$ & M; MPP & M; MPP \\
\hline Coxackieviruses & HFM; atypical exanthems; AGEP; GCS & $\mathrm{EV} ; \mathrm{MP}$ & EV; MP \\
\hline Echoviruses & HFM; atypical exanthems; AGEP & M; MP; MPP; U & EV; MP \\
\hline Enteroviruses & HFM; atypical exanthems; AGEP & EV; MP & EV \\
\hline $\begin{array}{l}\text { Adenoviruses and other respiratory } \\
\text { viruses }\end{array}$ & $\begin{array}{l}\text { Atypical exanthems; AGEP; GCS; } \\
\text { APEC }\end{array}$ & M; MP; EV; PE & MP; MPP \\
\hline Rotavirus & Atypical exanthems & $\mathrm{M} ; \mathrm{MP}$ & \\
\hline Hepatitis B and C viruses & Atypical exanthems; AGEP & M & \\
\hline Human immunodeficiency virus & Seroconversion illness & MP & $\mathrm{M} ; \mathrm{MP}$ \\
\hline Arboviruses & Atypical exanthems & MP; MPP & MP; MPP \\
\hline $\begin{array}{l}\text { Viruses responsible for hemorrhagic } \\
\text { fevers }\end{array}$ & Atypical exanthems & MPP; PE & MPP; PE \\
\hline \multicolumn{4}{|l|}{ Bacteria } \\
\hline $\begin{array}{l}\text { Streptococcus pyogenes; } \\
\text { Staphylococcus aureus }\end{array}$ & Atypical exanthems; TSS & M; MP; MPP & MP \\
\hline Rickettsia rickettsii & Rocky Mountain spotted fever & M; MP; MPP & \\
\hline Rickettsia prowazekii & Epidemic typhus & $\mathrm{M} ; \mathrm{MP}$ & \\
\hline Rickettsia typhi and Rickettsia felis & Murine Typhus & $\mathrm{M} ; \mathrm{MP}$ & \\
\hline Rickettsia conorii & Mediterranean spotted fever & MP; MPP; VP & \\
\hline Rickettsia akari & Rickettsialpox & PV & V \\
\hline Rickettsia tsutsugamushi & Scrub typhus & MP & \\
\hline $\begin{array}{l}\text { Anaplasma phagocytophilum and } \\
\text { Ehrlichia chaffeensis }\end{array}$ & Anaplasmosis and Erlichiosis & MP; MPP & $\mathrm{PE}$ \\
\hline Treponema pallidum & Secondary syphilis & $\mathrm{M} ; \mathrm{MP}$ & $P$ \\
\hline Neisseria meningitidis & Atypical exanthem & M; MP; PE & PE \\
\hline Neisseria gonorrhea & Atypical exanthem & M; MP; V; PU; PE; U & \\
\hline Staphilococcus aureus & Atypical exanthems & M; MP; PE & $\mathrm{PE}$ \\
\hline Escherichia coli & Atypical exanthems & MP & \\
\hline Klebsiella pneumoniae & Atypical exanthems & MP & \\
\hline Salmonella typhi & Atypical exanthems & MP & \\
\hline Shigella species & Atypical exanthems & MP & \\
\hline $\begin{array}{l}\text { Yersinia enterocolitica and } \\
\text { Y.pseudotuberculosis }\end{array}$ & Atypical exanthems & MP; PV & \\
\hline
\end{tabular}


Table 5. Common infectious agents causing exanthems and enanthems: morphology of the skin and mucosal lesions (cont.).

\begin{tabular}{|c|c|c|c|}
\hline Agent & Disease & Exanthem morphology & Enanthem morphology \\
\hline \multicolumn{4}{|l|}{ Bacteria } \\
\hline $\begin{array}{l}\text { Chlamydia psittaci, C. trachomatis, } \\
\text { Arcanobacterium hemoliticum, } \\
\text { Streptococcus pyogenes, } \\
\text { Streptococcus dysagalactiae, Borrelia } \\
\text { burgdorferi and Haemophilus } \\
\text { influenzae }\end{array}$ & Atypical exanthems & MP & \\
\hline Pseudomonas aeruginosa & Atypical exanthems & $\mathrm{P} ; \mathrm{PU}$ & \\
\hline Bartonella henselae and B. quintana & Atypical exanthems & $\mathrm{P}$ & \\
\hline Brucella species & Atypical exanthems & M & \\
\hline Legionella pneumophila & Atypical exanthems & MP & \\
\hline Fusobacterium necrophorum & Atypical exanthems & MP & \\
\hline \multicolumn{4}{|l|}{ Parasites } \\
\hline Toxoplasma gondii & Atypical exanthems & $M P ; P ; P V ; P E$ & \\
\hline Plasmodium vivax & Atypical exanthems & MP; U & \\
\hline Plasmodium falciparum & Atypical exanthems & $\mathrm{M} ; \mathrm{PE}$ & \\
\hline \multicolumn{4}{|l|}{ Helminths } \\
\hline Enterobius vermicularis & Atypical exanthems & M & \\
\hline Ascaris lumbricoides & Atypical exanthems & $\mathrm{U}$ & \\
\hline Toxocara canis; Toxocara cati & Atypical exanthems & $\mathrm{MP} ; \mathrm{V}$ & \\
\hline Schistosomes & Atypical exanthems & M; PV; PU; U; PE & \\
\hline
\end{tabular}

Francisella tularensis is a Gram-negative, pleomorphic bacillus which causes tularemia, a reemerging disease worldwide. Francisella resides in more than 100 species of animals and the infection usually follows contact with infected animals or their bite. Tularemia can be divided in systemic form (without indication of the inoculation site) and the most common ulceroglandular form (primary lesions on the hands with regional lymphadenitis). Multiple organs may be involved and dissemination of the infection may occur. The onset of any of the forms is sudden with fever, chills, headache and arthromyalgias. A painful papule appears at the site of inoculation that become an ulcer cover by an eschar associated to regional lymphnodes enlargement. From 6 to $30 \%$ of all forms of tularemia are accompanied by generalized maculopapular/petechial exanthems [87].

Listeria monocytogenes is a Gram-positive bacterium acquired by contaminated food, contaminated soil or inhalation of the bacterium. In immunocompetent adults the infection cause a mild illness with nonspecific symptoms (fever, nausea, vomiting and diarrhea). In immunocompromised patients, it may cause CNS involvement, endocarditis, pneumonia, osteomyelitis and arthritis. In pregnancy, the infection may lead to fetal transplacental infection. Neonatal listeriosis may be presents as early or late onset listeriosis. Early onset listeriosis may result in stillborn, premature birth or sepsis, pulmonary, hepatic, gastrointestinal or neurologic involvement. The newborn may present dark red papular, pustular/petechial skin eruption on trunk and legs or a generalized maculopapular exanthem that is the clue for listeria neonatal infection [88]. Late onset meningitis and septicemia are acquired through vaginal transmission. Neonatal late-onset and adult listeriosis cutaneous eruptions have rarely been described. Direct inoculation of listeria 


\section{Table 6. Clinical features and diagnostic methods of viral exanthems.}

\begin{tabular}{|c|c|c|c|c|}
\hline Virus & $\begin{array}{l}\text { Incubation } \\
\text { period }\end{array}$ & $\begin{array}{l}\text { Clinical features in addition } \\
\text { to rash }\end{array}$ & Laboratory diagnosis & Comments on diagnosis \\
\hline Enterovirus & $3-10$ days & $\begin{array}{l}\text { Aseptic meningitis, } \\
\text { encephalitis, acute } \\
\text { flaccid paralysis, upper } \\
\text { respiratory tract infection, } \\
\text { myopericarditis }\end{array}$ & $\begin{array}{l}\text { NAT: respiratory tract samples, CSF, } \\
\text { blood } \\
\text { IFA: respiratory samples } \\
\text { Serology: detection of Neutralizing } \\
\text { Antibodies }\end{array}$ & $\begin{array}{l}\text { NAT: routine qualitative assays have poor } \\
\text { clinical sensitivity }\end{array}$ \\
\hline $\begin{array}{l}\text { Parvovirus } \\
\text { B19 }\end{array}$ & 4-14 days & $\begin{array}{l}\text { Arthropathy, hydropsfetalis } \\
\text { and intrauternine death } \\
\text { myopericarditis }\end{array}$ & $\begin{array}{l}\text { Serology: Parvovirus B19-specific lgM } \\
\text { NAT: blood, bone marrow, placenta, } \\
\text { amniotic fluid, fetal tissue }\end{array}$ & $\begin{array}{l}\operatorname{lgM} \text { is detectable at } 2 \text { weeks with the } \\
\text { conclusion of the viremia. IgG appears } \\
\text { around } 1 \text { week later with rash }\end{array}$ \\
\hline HSV & 2-7 days & $\begin{array}{l}\text { Hepatitis, disseminated } \\
\text { disease in } \\
\text { immunocompromised hosts }\end{array}$ & $\begin{array}{l}\text { NAT: vesicular fluid, skin biopsy, } \\
\text { respiratory samples, CSF } \\
\text { IFA: vesicular fluid, skin biopsy, } \\
\text { respiratory samples } \\
\text { Viral culture: vesicular fluid, skin } \\
\text { biopsy, respiratory samples }\end{array}$ & $\begin{array}{l}\text { Serology is not generally useful. IgG may } \\
\text { confirm prior exposure to HSV } \\
\text { NAT has a higher sensitivity than culture } \\
\text { and immunofluorescence can provide } \\
\text { rapid diagnosis } \\
\text { Viral culture is necessary to establish } \\
\text { antiviral susceptibilities }\end{array}$ \\
\hline VZV & $10-21$ days & $\begin{array}{l}\text { Herpes zoster ophthalmicus, } \\
\text { acute retinal necrosis, } \\
\text { herpes zoster oticus, aseptic } \\
\text { meningitis, encephalitis, } \\
\text { postherpetic neuralgia, stroke } \\
\text { syndrome }\end{array}$ & $\begin{array}{l}\text { NAT: vescicular fluid, CSF } \\
\text { IFA: vesicular fluid, CSF Serology: VZV- } \\
\text { specific lgM }\end{array}$ & $\begin{array}{l}\text { Varicella is highly contagious. Clinical } \\
\text { findings are usually sufficient to make the } \\
\text { diagnosis NAT is highly specific } \\
\text { Serology is not generally useful } \\
\text { lgG may confirm prior exposure to VZV, } \\
\text { most useful in establishing risk following } \\
\text { contact in the antepartum period }\end{array}$ \\
\hline EBV & $4-8$ weeks & & $\begin{array}{l}\text { Serology: EBV-specific VCA IgM; EBNA } \\
\text { IgG; early antigen IgG } \\
\text { NAT: qualitative assays in tissue } \\
\text { specimens, quantitative assays in } \\
\text { blood }\end{array}$ & $\begin{array}{l}\text { EBV VCA IgM has good specificity in } \\
\text { the acute phase. In infants, it has a } \\
\text { lower sensitivity, and looking for lgG } \\
\text { seroconversion is important. EBNA } \\
\text { IgG persists for life after infection, and } \\
\text { antibodies to early antigen are generally } \\
\text { positive for up to } 2 \text { years after the acute } \\
\text { phase }\end{array}$ \\
\hline CMV & 4-12 weeks & $\begin{array}{l}\text { Mononucleosis } \\
\text { syndrome, reactivation } \\
\text { in critically unwell or } \\
\text { immunocompromised hosts }\end{array}$ & $\begin{array}{l}\text { Serology: CMV-specific lgM } \\
\text { NAT: qualitative assays in tissue } \\
\text { specimens, quantitative assays in } \\
\text { blood }\end{array}$ & $\begin{array}{l}\text { CMV-specific IgM is detectable within } \\
2 \text { weeks of exposure and falls over several } \\
\text { months. It is also detectable during } \\
\text { reactivation. Low-level CMV viremia } \\
\text { detected by NAT is usually not significant } \\
\text { in the absence of end organ CMV disease }\end{array}$ \\
\hline HHV-6 & 5-15 days & $\begin{array}{l}\text { Encephalitis and probably } \\
\text { multiple slcerosis in } \\
\text { immunocompetent } \\
\text { hosts, reactivation in } \\
\text { immunocompromised hosts }\end{array}$ & $\begin{array}{l}\text { Serology } \\
\text { NAT: qualitative and quantitative } \\
\text { assays in blood }\end{array}$ & $\begin{array}{l}\text { HHV- } 6 \text { can integrate into host } \\
\text { chromosomes, and in a small proportion } \\
\text { of cases, transmitted vertically and found } \\
\text { in all host nuclei }\end{array}$ \\
\hline HHV-8 & Unknown & $\begin{array}{l}\text { KS, primary effusion } \\
\text { lymphoma, Castleman's } \\
\text { disease Reactivation in } \\
\text { immunocompromised hosts }\end{array}$ & $\begin{array}{l}\text { Serology } \\
\text { NAT: qualitative and quantitative } \\
\text { assays in blood plasma, skin, lymph } \\
\text { nodes, lungs, Gl tract }\end{array}$ & $\begin{array}{l}\text { HHV-8 Plasma viremia is a marker of active } \\
\text { AIDS-KS disease }\end{array}$ \\
\hline $\begin{array}{l}\text { Measles } \\
\text { virus }\end{array}$ & $7-21$ days & $\begin{array}{l}\text { Prodrome of fever, } \\
\text { malaise followed by } \\
\text { conjunctivitis, coryza } \\
\text { and cough; encephalitis, } \\
\text { acute disseminated } \\
\text { encephalomyelitis, subacute } \\
\text { sclerosing panencephalitis }\end{array}$ & $\begin{array}{l}\text { Serology: measles-specific lgM } \\
\text { IFA and NAT: in respiratory and/or } \\
\text { urine specimens }\end{array}$ & $\begin{array}{l}\text { Sensitivity of measles-specific lgM is } 67 \% \text { if } \\
\text { serum is collected }<72 \mathrm{~h} \text { after the onset of } \\
\text { rash. Cross-reactivity from parvovirus B19, } \\
\text { rubella and HHV-6 } \\
\text { Sensitivity of IFA reported to be } 46-54 \%\end{array}$ \\
\hline
\end{tabular}




\begin{tabular}{|c|c|c|c|c|}
\hline Virus & $\begin{array}{l}\text { Incubation } \\
\text { period }\end{array}$ & $\begin{array}{l}\text { Clinical features in addition } \\
\text { to rash }\end{array}$ & Laboratory diagnosis & Comments on diagnosis \\
\hline Rubella & $15-20$ days & $\begin{array}{l}5 \text { days prodrome of fever, } \\
\text { headache and upper } \\
\text { respiratory tract symptoms; } \\
\text { arthralgias involving the } \\
\text { wrists, elbows and ankles } \\
\text { lasting up to } 3 \text { weeks; } \\
\text { more severe complications } \\
\text { include hemolytic anemia, } \\
\text { thrombocytopenia, } \\
\text { pericarditis, myocarditis and } \\
\text { encephalitis }\end{array}$ & $\begin{array}{l}\text { Serology: rubella-specific lgM } \\
\text { NAT: nasal, blood, urine or CSF }\end{array}$ & $\begin{array}{l}\text { Serum best collected } 7-10 \text { days after } \\
\text { onset of the rash and repeated } 2-3 \text { weeks } \\
\text { later. Acute rubella may be diagnosed } \\
\text { by presence of rubella-specific IgM, a } \\
\text { fourfold rise in IgG between acute and } \\
\text { convalescent }\end{array}$ \\
\hline
\end{tabular}

in the skin of veterinarians who have exposure to animal products of conception or gardeners may hesitate in nonpainful, nonpruritic, papulopustular or papulovesicular eruptions that are usually self-limited and resolve without antibiotic treatment [88].

Acinetobacter species are highly resistant, opportunistic, pleomorphic aerobic Gramnegative bacteria commonly isolated from the hospital environment and hospitalized patients, capable of causing infection in immunocompromised patients. Among Acinetobacter species, Acinetobacter baumanii accounts for the most of the infections and may involve any organ, including skin and soft tissues; disseminated infection may occur causing abscess formations. A diffuse maculopapular rash with petechiae involving trunk, limbs, palms and soles has been reported in early prosthetic valve endocarditis [89].

Fusobacterium necrophorum is an anaerobic Gram-negative bacterium causing acute pharyngotonsillitis that may lead to peritonsillar cellulitis with thrombophlebitis of the internal jugular vein. A nonpruritic painful maculopapular rash on the extremities has been described during this infection [90].

\section{Parasitic exanthems}

Toxoplasma gondii is acquired by ingestion of contaminated food/water or in utero. Cutaneous toxoplasmosis occurs as congenital or acquired infection (including acute and reactivated forms). In toxoplasma infection, cutaneous involvement occurs in less than $10 \%$ of immunocompetent patients, but the frequency may be greater in immunocompromised hosts. In acquired infections, cutaneous lesions may be maculopapular, papulopustular, vesicular, nodular, purpuric or lichenoid. In congenital infections, skin lesions are usually hemorrhagic/necrotic papules on the trunk [1,3,91].

During malaria caused by Plasmodium vivax and Plasmodium falciparum petechiae and purpura have been reported $[92,93]$. More specifically, maculopapular skin eruptions and urticarial lesions occur in malaria by Plasmodium vivax [92]. Asymptomatic reticulate erythema with petechiae involving upper and lower limbs has been associated with malaria by P. falciparum [93].

\section{Helminths exanthems}

Rare cases of exanthems related to helminths have been described. Transmission occurs by ingestion of contaminated food (especially fruits/vegetables) with mature eggs of the worm. A macular exanthem has been described during Enterobius vermicularis infection whereas Ascaris lumbricoides can cause urticarial lesions, both associated with pruritus [1,94]. Strongyloides stercoralis infection may cause a characteristic thumbprint periumbilical purpura due to larvae transmigration across the vascular endothelium into the dermis with red cells extravasation [94]. Toxocariasis is an infection caused by the ingestion of larvae of the dog roundworm Toxocara canis or the cat roundworm Toxocara cati. It may presents with pruritic eosinophilic folliculitis diffuse over face, trunk and upper extremities and a widespread erythematous, maculopapular/ vesicular eruption involving abdomen, thighs, upper arms and palms [95]. Cercarial or schistosome dermatitis is an acute eruption caused by an immunologic reaction to the cercarial stage 


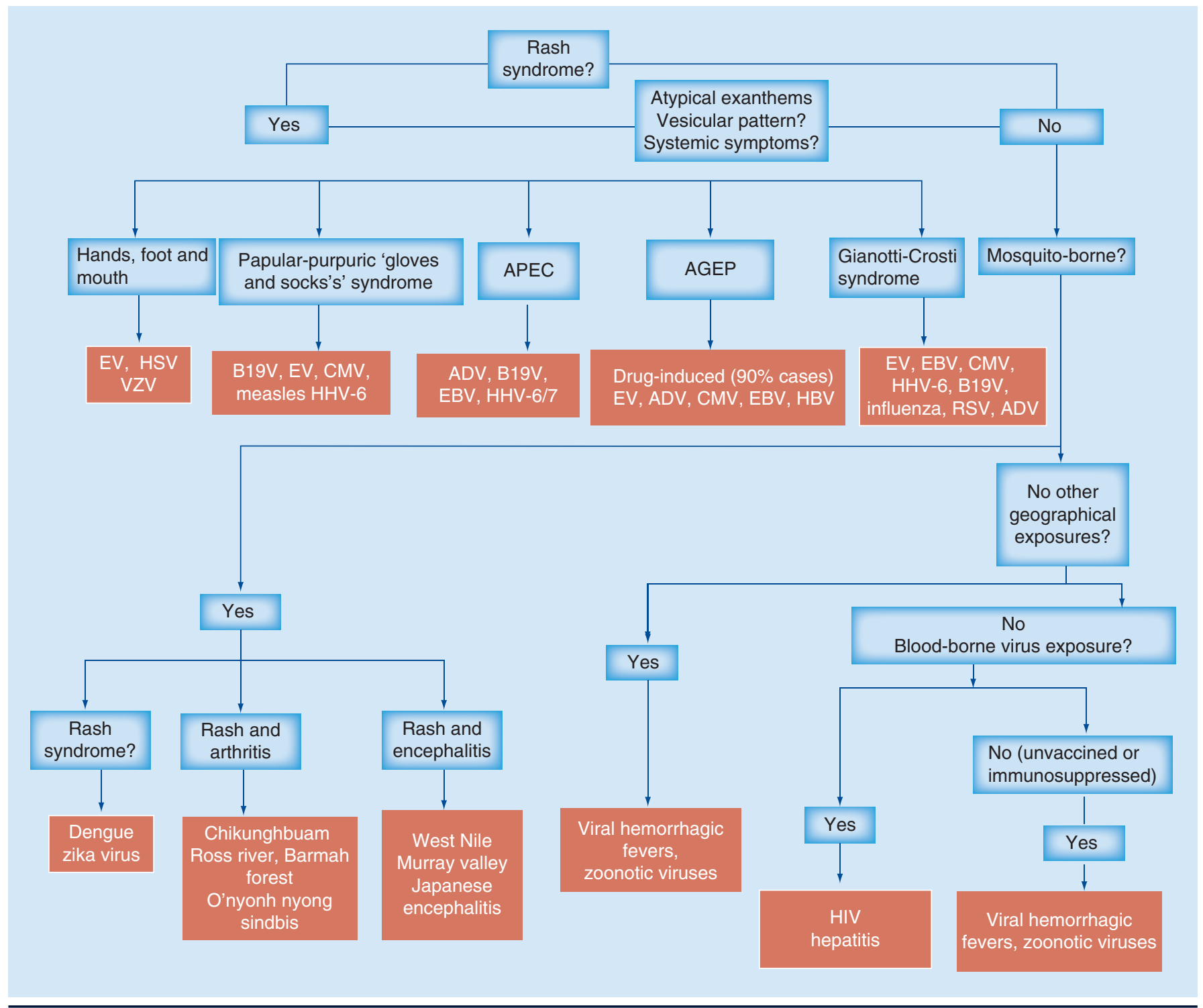

Figure 11. Flow chart of a preclinical approach used to determine possible viral etiologies of exanthems.

AGEP: Acute generalized exanthematous pustolosis; APEC: Asymmetric periflexural exanthem of childhood; B19V: Parvovirus B19; CMV: Cytomegalovirus; EBV: Epstein-Barr virus; EV: Erythematovesicular; HHV: Human herpesvirus; HSV: Herpes simplex virus; VZV:

Varicella zoster virus.

of nonhuman schistosomes, whose hosts are birds and small mammals. Schistosomes which cause invasive disease in humans may cause a similar skin eruption soon after exposure to the helminth. On re-exposure after sensitization, the rash may begin sooner and be more severe. A pruritic, erythematous macular eruption develops and may progress to papulovesicular/pustular/ urticarial lesions. Petechiae and purpura may be present. The rash spares area of the body covered by clothing [96]. Patients affected by Trichinosis, caused by Trichinella spiralis, may present periorbital edema, conjunctival hemorrhages, splinter hemorrhages of the fingernails and maculopapular/urticarial eruption on the limbs. In 10\% of them, bilateral asymptomatic hand swelling and macular erythema of the palms occur and resolve with desquamation [97].

\section{- Diagnosis}

In two of our previous studies, we found a relationship between morphological pattern of the exanthem and etiology $[1,3]$ : the erythematousvesicular pattern was primarily related to viral infections and the urticarial pattern with parasitic infections. The maculopapular pattern was 


\section{EXECUTIVE SUMMARY}

\section{Atypical exanthems}

- An exanthem is defined as any eruptive skin rash that may be associated with lesions of the mucous membranes (enanthem), fever or systemic symptoms.

- Beside the 'classic exanthems,' other exanthems with different morphology and caused by different infectious/toxic agents may occur ('atypical exanthems'). Among the atypical exanthems with infectious etiology, viral, bacterial, parasitic and helminths infections are implicated.

\section{Viruses}

- Many viral infections are responsible for atypical exanthems. The main correlations between virus and type of exanthem are listed below. Herpes simplex virus (HSV)-1 and 2 are related to eczema herpeticum; varicella zoster virus to shingles; cytomegalovirus and Epstein-Barr virus to maculopapular exanthems; Human herpesvirus (HHV) 6 and HHV-7 to Pityriasis rosea; HHV-8 to Kaposi's sarcoma; B19V to maculopapular/purpuric eruptions; enteroviruses to hand-foot-mouth syndrome and maculopapular or papulo/vesicular eruptions; respiratory viruses and rotavirus to mild maculopapular exanthems; hepatitis $B$ virus and hepatitis $C$ virus to macular reticular rashes; HIV to generalized maculopapular rash; arboviruses with maculopapular/petechial exanthems. Viral exanthems are often associated with enanthem.

\section{Bacteria}

- Many bacterial infections are responsible for atypical exanthems. The main correlations between bacterium and type of exanthem are listed below. Streptococcus pyogenes (group A) and Staphylococcus aureus may be related to the macular erythroderma of the toxic shock syndrome; Rickettsiae to maculopapular exanthems that often become petechial/purpuric; Anaplasma phagocytophilum and Ehrlichia chaffeensis to maculopapular or petechial exanthem; secondary syphilis is associated with a symmetrical, pink or coppery-red macular eruption; Neisseria meningitidis and gonorrhea with erythematous macular/maculopapular eruptions; Enterobacteriaceae may cause maculopapular rashes. Many other bacteria (Chlamydia psittaci and trachomatis, Arcanobacterium hemoliticum, Streptococcus pyogenes, Streptococcus dysagalactiae, Borrelia burgdorferi, Haemophilus influenzae and others) may be related to skin eruptions with different morphology (maculopapular/vesicular/pustular exanthems).

\section{Parasites}

- Toxoplasma gondii may be associated, in acquired infections, with maculopapular, papulopustular, vesicular, nodular, purpuric or lichenoid eruptions. In congenital infections, skin lesions are usually hemorrhagic/necrotic papules. Plasmodium vivax and Plasmodium falciparum may cause petechial/purpuric skin eruptions..

\section{Helminths}

- Rare cases of exanthems related to helminths have been described. A macular exanthem has been described during Enterobius vermicularis infection, whereas Ascaris lumbricoides can cause urticarial lesions. Toxocara canis or Toxocara cati may be associated with a widespread erythematous, maculopapular/vesicular eruption.

\section{Relationship between morphological pattern of the exanthem \& etiology}

- The erythematous-vesicular pattern was primarily related to viral infections and the urticarial pattern with parasitic infections. The maculopapular pattern was almost evenly distributed among the various etiologies, although the color was duskier in drug-related exanthems. Enanthems were most often infectious in nature, especially viral.

\section{Laboratory diagnosis}

- Specific serology is not sufficient by itself to identify an active infection. The detection of pathogen-specific lgM reveals a viral reactivation or a primary infection. IgG seroconversion is considered evidence of infection: at least a four-times difference in IgG titers in two consequential samples (collected in the acute and convalescent phases) of the same patient may be helpful. Nested PCR techniques can be used to detect the viral DNA in plasma or serum, a wellknown marker of active viral replication and active infection. Although culture tests are slow and have low sensitivity, they remain the gold standard for diagnosis of infections for which molecular methods, such as nested PCR, are validated against. 


\section{EXECUTIVE SUMMARY (CONT.)}

\section{Importance of the diagnosis}

- Etiological diagnosis of the atypical exanthems especially the infectious ones, remains difficult but crucial for both the patient and community concerning issues such as time off school, immunizations and risk for pregnant women and immunocompromised patients.

almost evenly distributed among the various etiologies, although the color was duskier in drugrelated exanthems (Table 5). Enanthems were most often infectious in nature, especially viral. Regarding seasonality, viral infections resulted more prevalent during spring/summer whereas bacterial infections during fall/winter $[1,3]$.

Laboratory examinations may help in identifying the causative infectious agent.

Specific serology is not sufficient by itself to identify an active infection. The detection of pathogen-specific IgM reveals a viral reactivation or a primary infection but one has to remember that cross-reactivity with other infectious agents may give false-positive results. IgG seroconversion is considered evidence of infection: at least a four-times difference in IgG titers in two consequential samples (collected in the acute and convalescent phases) of the same patient may be helpful. To differentiate acute from previous infection, it is useful to determine the maturity of the $\mathrm{IgG}$ response through the measurement of IgG avidity. High IgG avidity points out a past or recurrent infection whereas low IgG avidity indicates a recent primary infection, even if only one serum sample is available $[98,99]$.

Nested PCR techniques can be used to detect the viral DNA in plasma or serum, a well-known marker of active viral replication and active infection $[7,18,36,100]$.

Antigen detection by immunofluorescence is used for the diagnosis of HSV and VZV infections. Although culture tests are slow and have low sensitivity, they remain the gold standard for diagnosis of infections for which molecular methods, such as nested PCR, are validated against (Table 6).

Histological examination usually does not provide a conclusive etiological diagnosis in infectious exanthems. Conversely, if the differential diagnosis includes a reaction to a drug, then a skin biopsy should be promptly performed, especially in life-threatening conditions such as DRESS syndrome [26,27], since it may help to elucidate the diagnosis. Immunohistochemistry with specific monoclonal antibodies is helpful to detect specific antigens belonging to virus/bacteria/parasites [101].

\section{Conclusion}

Understanding the etiology of atypical exanthems, especially the infectious ones, remains difficult but crucial for patient and community concerning issues such as time off school, immunizations, risk for pregnant women and immunocompromised patients. However, the morphological patterns, seasonal occurrence, presence of enanthem and systemic symptoms may offer the physician important clues to make a quick etiological diagnosis (Figure 11), which, if confirmed by tests, ensures timely and appropriate treatment.

\section{Future perspective}

In case of viral exanthems, the management is mainly supportive because of the lack of specific antiviral therapies. Nowadays, viral exanthems are becoming more common due to the decline of vaccination rates, the increase of the global population, the vector movements and the emerging novel viruses. Moreover, new immunosuppressive therapies have led to higher rates of reactivation of latent viruses. Clinicians should be alert and trained to recognize atypical presentations of established viruses and other infectious agents. Measures of infection control remain the main strategy to limit further transmission of infections.

\section{Financial \& competing interests disclosure}

The authors have no relevant affiliations or financial involvement with any organization or entity with a financial interest in or financial conflict with the subject matter or materials discussed in the manuscript. This includes employment, consultancies, honoraria, stock ownership or options, expert testimony, grants or patents received or pending, or royalties.

No writing assistance was utilized in the production of this manuscript.

\section{Open access}

This work is licensed under the Creative Commons Attribution-NonCommercial 4.0 Unported License. To view a copy of this license, visit http://creativecommons.org/ licenses/by-nc-nd/4.0/ 


\section{References}

Papers of special note have been highlighted as: - of interest; $\bullet$ of considerable interest

1 Drago F, Rampini E, Rebora A. Atypical exanthems: morphology and laboratory investigations may lead to an aetiological diagnosis in about $70 \%$ of cases. $\mathrm{Br}$. J. Dermatol. 147, 255-260 (2002).

-• Describes the features of the infectious exanthems that have been extensively reported in this review, in an updated version.

2 Bialecki C, Feder HM Jr, Grant-Kels JM. The six classic childhood exanthems: a review and update. J. Am. Acad. Dermatol. 21, 891-903 (1989).

3 Drago F, Paolino S, Rebora A et al. The challenge of diagnosing atypical exanthems: a clinico-laboratory study. J. Am. Acad. Dermatol. 67, 1282-1288 (2012).

-. Describes the features of the infectious exanthems that have been extensively reported in this review, in an updated version.

4 Fölster-Holst R, Zawar VP, Chuh A. Paraviral exanthems. Expert Rev. Anti Infect. Ther. 14, 601-611 (2016).

5 Lipsker D, Saurat JH. A new concept: paraviral eruptions. Dermatology 211, 309-311 (2005).

6 Cherry JD. Viral exanthems. Curr. Probl. Pediatr. 13, 1-44 (1983).

-• Describes the features of the infectious exanthems that have been extensively reported in this review, in an updated version.

7 Ramdass P, Mullick S, Farber HF. Viral skin diseases. Prim. Care 42, 517-567 (2015).

-. Describes the features of the infectious exanthems that have been extensively reported in this review, in an updated version.

8 Ferrari B, Taliercio V, Luna P, Abad ME, Larralde M. Kaposi's varicelliform eruption: a case series. Indian Dermatol. Online J. 6, 399-402 (2015).

9 Gershon AA, Gershon MD. Pathogenesis and current approaches to control of varicellazoster virus infections. Clin. Microbiol. Rev. 26, 728-743 (2013).

10 Drago F, Aragone MG, Lugani C, Rebora A. Cytomegalovirus infection in normal and immunocompromised humans. A review. Dermatology 200, 189-195 (2000).

11 Weigand DA, Burgdorf WH, Tarpay MM. Vasculitis in cytomegalovirus infection. Arch. Dermatol. 116, 1174-1176 (1980).
12 Drago F, Javor S, Ciccarese G, Parodi A. Gianotti-Crosti syndrome as presenting sign of cytomegalovirus infection: a case report and a critical appraisal of its possible cytomegalovirus etiology. J. Clin. Virol. 78, 120-122 (2016)

13 Roujeau JC, Bioulac-Sage P, Bourseau C et al. Acute generalized exanthematous pustulosis analysis of 63 cases. Arch. Dermatol. 127, 1333-1338 (1991).

14 Di Lernia V, Mansouri Y. Epstein-Barr virus and skin manifestations in childhood. Int. J. Dermatol. 52, 1177-1184 (2013).

15 Picard D, Janela B, Descamps V et al. Drug reaction with eosinophilia and systemic symptoms (DRESS): a multiorgan antiviral T-cell response. Sci. Transl. Med. 2, 46ra62 (2010).

16 Drago F, Crovato F, Rebora A. GianottiCrosti syndrome as a presenting sign of EBV-induced acute infectious mononucleosis. Clin. Exp. Dermatol. 22, 301-302 (1997).

17 Drago F, Rebora A. The new herpesviruses: emerging pathogens of dermatological interest. Arch. Dermatol. 135, 71-75 (1999).

18 Kempf W, Adams V, Kleinhans M et al. Pityriasis rosea is not associated with humanherpesvirus 7. Arch. Dermatol. 135 1070-1072 (1999).

19 Kosuge H, Tanaka-Taya K, Miyoshi H et al. Epidemiological study of human herpesvirus- 6 and human herpesvirus-7 in pityriasis rosea. Br. J. Dermatol. 143, 795-798 (2000).

20 Drago F, Ranieri E, Malaguti F, Losi E, Rebora A. Human herpesvirus 7 in pityriasis rosea. Lancet 349, 1367-1368 (1997).

21 Watanabe T, Kawamura T, Jacob SE et al. Pityriasis rosea is associated with systemic active infection with both human herpesvirus-7 and human herpesvirus- 6 . J. Invest. Dermatol. 119, 793-797 (2002).

22 Drago F, Malaguti F, Ranieri E, Losi E, Rebora A. Human herpes virus-like particles in pityriasis rosea lesions: an electron microscopy study. J. Cutan. Pathol. 29, 359-361 (2002).

23 Broccolo F, Drago F, Careddu AM et al. Additional evidence that pityriasis rosea is associated with reactivation of human herpesvirus-6 and -7. J. Invest. Dermatol. 124, 1234-1240 (2005).

24 Drago F, Broccolo F, Rebora A. Pityriasis rosea: an update with a critical appraisal of its possible herpesviral etiology. J. Am. Acad. Dermatol. 61, 303-318 (2009).

25 Yoshikawa T, Asano Y, Ihira M et al. Human herpesvirus 6 viremia in bone marrow transplant recipients: clinical features and risk factors. J. Infect. Dis. 185, 847-845 (2002).

26 Broccolo F, Ciccarese G, Picciotto A, Drago F. A case of drug rash with eosinophilia and systemic symptoms (DRESS) induced by telaprevir associated with HHV-6 active infection. J. Hepatol. 62(1) 248-249 (2015).

27 Drago F, Cogorno L, Broccolo F, Ciccarese G, Parodi A. A fatal case of DRESS induced by strontium ranelate associated with HHV-7 reactivation. Osteoporos Int. 27, 1261-1264 (2016).

28 Ruzicka T, Kalka K, Diercks K, Schuppe HC Papular-purpuric 'gloves and socks' syndrome associated with human herpesvirus 6 infection. Arch. Dermatol. 134, 242-244 (1998).

29 Yasumoto S, Tsujita J, Imayama S, Hori Y. Case report: Gianotti-Crosti syndrome associated with human herpesvirus-6 infection. J. Dermatol. 23, 499-501 (1996).

30 Wyplosz B, Carlotti A, Escaut L et al. Initial human herpesvirus- 8 rash and multicentric Castleman disease. Clin. Infect. Dis. 47, 684-688 (2008).

31 Dagna L, Broccolo F, Paties CT et al. A relapsing inflammatory syndrome and active human herpesvirus 8 infection. N. Engl. J. Med. 353, 156-163 (2005).

32 Servant-Delmas A, Lefrère JJ, Morinet F, Pillet S. Advances in human B19 erythrovirus biology. J. Virol. 84, 9658-9665 (2010).

33 Drago F, Ciccarese G, Broccolo G, Javor S, Parodi A. Atypical exanthems associated with Parvovirus B19 (B19V) infection in children and adults. J. Med. Virol. 87, 1981-1984 (2015).

34 Harms M, Feldmann R, Saurat JH. Papular-purpuric 'gloves and socks' syndrome. J. Am. Acad. Dermatol. 23, 850 (1990).

35 Gutermuth J, Nadas K, Zirbs M et al. Papular-purpuric gloves and socks syndrome. Lancet 378(9786), 198 (2011)

36 Cherry JD. Contemporary infectious exanthems. Clin. Infect. Dis. 16, 199-205 (1993).

-. Describes the features of the infectious exanthems that have been extensively reported in this review, in an updated version.

37 Feder HM Jr, Bennett N, Modlin JF. Atypical hand, foot, and mouth disease: a vesiculobullous eruption caused by Coxsackie virus A6. Lancet Infect. Dis. 14, 83-86 (2014).

38 Steigman AJ, Lipton MM, Braspennickx $\mathrm{H}$. Acute lymphonodular pharyngitis: a newly described condition due to Coxsackie A virus. J. Pediatr. 61, 331-336 (1962). 
39 Feldman RG, Bryant J, Ives KN, Hill NC. A novel presentation of Coxsackie B2 virus infection during pregnancy. J. Infect. 15, 73-76 (1987).

40 Feldman R, Harms M, Saurat JH. Papularpurpuric 'gloves and socks' syndrome: not only parvovirus B19. Dermatology 188, 85-87 (1994).

41 Drago F, Ciccarese G, Broccolo F, Toniolo A, Javor S, Parodi A. Localized exanthem due to echovirus 9. J. Med. Virol. 87, 1447-1448 (2015).

42 Cherry JD, Lerner AM, Klein JO, Finland M. Echo 11 virus infections associated with exanthems. Pediatrics 32, 509-516 (1963).

43 Morens DM. Boston exanthem agent: echovirus 16. Am. J. Dis. Child. 131, 1306 (1977).

44 Prose NS, Tope W, Miller SE, Kamino H. Eruptive pseudoangiomatosis: a unique childhood exanthem? J. Am. Acad. Dermatol. 29, 857-859 (1993).

45 Jansson E, Wager O, Forssell P, Halonen $\mathrm{H}$. An exanthema subitum-like rash in patients with adenovirus infections. Ann. Paediatr. Fenn. 7, 274-282 (1961)

46 Wang X, Yang K, Wei C, Huang Y, Zhao D. Coinfection with EBV/CMV and other respiratory agents in children with suspected infectious mononucleosis. Virol. J. 7, 247-256 (2010).

47 Skowronski DM, Chambers C, Osei Wet al. Case series of rash associated with influenza B in school children. Influenza Other Respir. Viruses 9, 32-37 (2015).

48 Kaley J, Pellowski DM, Cheung WL, Hiatt $\mathrm{KM}$. The spectrum of histopathologic findings in cutaneous eruptions associated with influenza A (H1N1) infection. J. Cutan. Pathol. 40, 226-229 (2013).

49 Hewitt HB, Munro TR. Rashes due to respiratory syncytial virus. $\mathrm{Br}$. Med. J. 2(5423), 1481-1482 (1964).

50 Zawar V, Bharatia P, Chuh A. Eruptive hypomelanosis - a novel exanthem associated with viral symptoms in children. JAMA Dermatol. 150, 1197-1201 (2014).

51 Drago F, Ciccarese G, Rebora A. Unilateral laterothoracic or asymmetric periflexural exanthem: is time to change the name of the disease? Clin. Exp. Dermatol. 40, 570 (2015).

52 Manzano S, Guggisberg D, Hammann C, Laubscher B. Acute generalized exanthematous pustulosis: first case associated with a Chlamydia pneumoniae infection. Arch. Pediatr. 13, 1230-1232 (2006).
53 Kappus MR, Sterling RK. Extrahepatic manifestations of acute hepatitis B virus infection. Gastroenterol. Hepatol. (NY) 9(2), 123-126 (2013).

54 Altman K, Vanness E, Westergaard RP. Cutaneous manifestations of human immunodeficiency virus: a clinical update. Curr. Infect. Dis. Rep. 17, 464 (2015).

55 Lupi O, Tyring SK. Tropical dermatology: viral tropical diseases. J. Am. Acad. Dermatol. 49, 979-1000 (2003)

56 Giudice PD, Schuffenecker I, Zeller $\mathrm{H}$ et al. Skin manifestations of West Nile virus infection. Dermatology 211, 348-350 (2006).

57 Center for Disease Control and Prevention [CDC]. Rift Valley fever. Signs and symptoms. www.cdc.gov/vhf/rvf/symptoms/index.html

58 Duffy MR, Chen TH, Hancock WT et al. Zika virus outbreak on Yap Island, Federated States of Micronesia. N. Engl. J. Med. 360 (24), 2536-2543 (2009).

59 Carneiro SC, Cestari T, Allen SH, Ramos e-Silva M. Viral exanthems in the tropics. Clin. Dermatol. 25, 212-220 (2007).

60 Bandyopadhyay D, Ghosh SK. Mucocutaneous features of chikungunya fever: a study from an outbreak in West Bengal, India. Int. J. Dermatol. 47, 1148-1152 (2008).

61 Nappe TM, Chuhran CM, Johnson SA. The chikungunya virus: an emerging US pathogen. World J. Emerg. Med. 7, 65-67 (2016).

62 Zammarchi L, Tappe D, Fortuna C et al. Zika virus infection in a traveller returning to Europe from Brazil, March 2015. Euro Surveill. 20, pii: 21153 (2015).

63 Cerbino-Neto J, Mesquita EC, Souza TM et al. Clinical manifestations of Zika virus infection, Rio de Janeiro, Brazil, 2015. Emerg. Infect. Dis. 22, 1318-1320 (2016).

64 Brasil P, Calvet GA, de Souza RV, Siqueira AM. Exanthema associated with Zika virus infection. Lancet Infect. Dis. 16, 866 (2016).

65 Cleri DJ, Ricketti AJ, Porwancher RB, Ramos-Bonner LS, Vernaleo JR. Viral hemorrhagic fevers: current status of endemic disease and strategies for control. Infect. Dis. Clin. North Am. 20, 359-393 (2006).

66 Choumet V, Desprès P. Dengue and other flavivirus infections. Rev. Sci. Tech. 34, 473-478, 467-472 (2015).

67 Manders SM. Toxin-mediated streptococcal and staphylococcal disease. J. Am. Acad. Dermatol. 39, 383-398; quiz 399-400 (1998).
68 Faccini-Martínez ÁA, García-Álvarez L, Hidalgo M, Oteo JA. Syndromic classification of rickettsioses: an approach for clinical practice. Int. J. Infect. Dis. 28, 126-139 (2014).

69 Center for Disease Control and Prevention. www.cdc.gov/rmsf/

70 Kemper CA, Spivack AP, Deresinski SC. Atypical papulovesicular rash due to infection with Rickettsia conorii. Clin. Infect. Dis. 15, 590-594 (1992).

71 St Clair K, Decker CF. Ehrlichioses: anaplasmosis and human ehrlichiosis. Dis. Mon. 58, 346-354 (2012).

72 Baughn RE, Musher DM. Secondary syphilitic lesion. Clin. Microbiol. Rev. 18, 205-216 (2005).

73 van de Beek D, de Gans J, Spanjaard L, Weisfelt M, Reitsma JB, Vermeulen M. Clinical features and prognostic factors in adults with bacterial meningitis. $N$. Engl. J. Med. 351, 1849-1859 (2004).

74 Rotbart HA, McCracken GH Jr, Whitley RJ. Clinical significance of enteroviruses in serious summer febrile illnesses of children. Pediatr. Infect. Dis. J. 18, 869-874 (1999).

75 Suzaki A, Hayashi K, Kosuge K, Soma M, Hayakawa S. Disseminated gonococcal infection in Japan: a case report and literature review. Intern. Med. 50, 2039-2043 (2011).

76 Caksen H, Uzum K, Yuksel S, Ustunbas HB Cutaneous manifestations in childhood staphylococcal sepsis. J. Dermatol. 29, 43-45 (2002).

77 Casacci M, Carpentier O, Truffert P, Piette F, Catteau B. Neonatal maculopapular exanthema revealing septicemia due to Klebsiella pneumoniae via maternofetal infection. Ann. Dermatol. Venereol. 133, 31-33 (2006).

78 Gilman RH, Terminel M, Levine MM, Hernandez-Mendoza P, Hornick RB. Relative efficacy of blood, urine, rectal swab, bone-marrow, and rose-spot cultures for recovery of Salmonella typhi in typhoid fever. Lancet 31, 1211-1213 (1975).

79 Belilos E, Tu RP, Sacks-Berg A, Strampfer MJ, Cunha BA. Rose spots associated with enteric fever secondary to Shigella sonnei. Int. J. Dermatol. 27, 402-403 (1988).

80 Weber L. Yersinia exanthema. Hautarzt 39, 773-778 (1988).

81 Fernandez-Acenero MJ, Fernandez-Lopez P. Cutaneous lesions associated with bacteremia by streptococcus dysgalactiae. J. Am. Acad. Dermatol. 55, S91-S92 (2006).

82 Canavan TN, Mathes EF, Frieden B, Shinkai K. Mycoplasma pneumoniae-induced rash 
and mucositis as a syndrome distinct from Stevens-Johnson syndrome and erythema multiforme: a systematic review. J. Am. Acad. Dermatol. 72, 239-245 (2015).

83 Zichichi L, Asta G, Noto G. Pseudomonas aeruginosa folliculitis after shower/bath exposure. Int. J. Dermatol. 39, 270-273 (2000).

Berger TG, Koehler JE. Bacillary angiomatosis. AIDS Clin. Rev. 43-60 (1993-1994).

85 Berger TG, Guill MA, Goette DK. Cutaneous lesions in brucellosis. Arch. Dermatol. 117, 40-42 (1981).

Cunha BA, Burillo A, Bouza E. Legionnaires disease. Lancet 387, 376-385 (2016).

87 Maurin M, Pelloux I, Brion JP, Del Banõ JN, Picard A. Human tularemia in France, 2006-2010. Clin. Infect. Dis. 53(10), e133-e134 (2011)

Godshall CE, Suh G, Lorber B. Cutaneous listeriosis. J. Clin. Microbiol. 51, 3591-3596 (2013).

Olut AI, Erkek E. Early prosthetic valve endocarditis due to Acinetobacter baumannii: a case report and brief review of the literature. Scand J. Infect. Dis. 37, 919-921 (2005).

90 Andany N, Showler A, Morris AM, Bogoch I. Photo quiz: a 50-year-old woman with fever, rash, and polyarthritis. Clin. Infect. Dis. 60(1388), 1436-1437 (2015).
91 Rand AJ, Buck AB, Love PB, Prose NS, Selim MA. Cutaneous acquired toxoplasmosis in a child: a case report and review of the literature. Am. J. Dermatopathol. 37, 305-310 (2015)

92 Vaishnani JB. Cutaneous findings in five cases of malaria. Indian J. Dermatol. Venereol. Leprol. 77, 110 (2011).

93 Varga M, Dumitrașcu D, Piloff L, Chioreanu E. Skin manifestations in parasite infection. Roum. Arch. Microbiol. Immunol. 60, 359-369 (2001)

94 Bank DE, Grossman ME, Kohn SR, Rabinowitz AD. The thumbprint sign: rapid diagnosis of disseminated strongyloidiasis. J. Am. Acad. Dermatol. 23, 324-326 (1990).

95 Bernardeschi C, Monsel G, Frances C, Bricaire F, Paris L, Caumes E. Febrile exanthema revealing toxocariasis: a case report. Acta Derm. Venereol. 91, 350-351 (2011).

96 Fölster-Holst R, Disko R, Röwert J, Böckeler W, Kreiselmaier I, Christophers E. Cercarial dermatitis contracted via contact with an aquarium: case report and review. $\mathrm{Br}$. J. Dermatol. 145, 638-640 (2001).

97 Walsh DS, Jongsakul K, Watt G. Hand rash in trichinosis. Clin. Exp. Dermatol. 26, 272-273 (2001).

Ward KN, Gray JJ, Fotheringham MW, Sheldon MJ. IgG antibodies to human herpesvirus- 6 in young children: changes in avidity of antibody correlate with time after infection. J. Med. Virol. 39, 131-138 (1993).

- Explains how it is possible to obtain a confirmatory laboratory diagnosis in case of clinically suspected infectious exanthems. Rebora A, Drago F, Broccolo F. Pityriasis rosea and herpesviruses: facts and controversies. Clin. Dermatol. 28, 497-501 (2010).

- Explains how it is possible to obtain a confirmatory laboratory diagnosis in case of clinically suspected infectious exanthems.

100 Broccolo F, Locatelli G, Sarmati L et al. A calibrated real-time PCR assay for the quantitation of human herpesvirus 8 DNA in biological fluids. J. Clin. Microbiol. 12, 4652-4658 (2002).

- Explains how it is possible to obtain a confirmatory laboratory diagnosis in case of clinically suspected infectious exanthems.

101 Molina-Ruiz AM, Santonja C, Rütten A, Cerroni L, Kutzner H, Requena L. Immunohistochemistry in the diagnosis of cutaneous viral infections- part II: cutaneous viral infections by parvoviruses, poxviruses, paramyxoviridae, picornaviridae, retroviruses and filoviruses. Am. J. Dermatopathol. 37, 93-106 (2015).

- Explains how it is possible to obtain a confirmatory laboratory diagnosis in case of clinically suspected infectious exanthems. 